\title{
Wind-driven changes in Southern Ocean residual circulation, ocean carbon reservoirs and atmospheric $\mathrm{CO}_{2}$
}

\author{
Jonathan M. Lauderdale • Alberto C. Naveira Garabato • \\ Kevin I. C. Oliver • Michael J. Follows • \\ Richard G. Williams
}

Received: 9 July 2012/ Accepted: 22 December 2012/Published online: 12 January 2013

(C) Springer-Verlag Berlin Heidelberg 2013

\begin{abstract}
The effect of idealized wind-driven circulation changes in the Southern Ocean on atmospheric $\mathrm{CO}_{2}$ and the ocean carbon inventory is investigated using a suite of coarse-resolution, global coupled ocean circulation and biogeochemistry experiments with parameterized eddy activity and only modest changes in surface buoyancy forcing, each experiment integrated for 5,000 years. A positive correlation is obtained between the meridional overturning or residual circulation in the Southern Ocean and atmospheric $\mathrm{CO}_{2}$ : stronger or northward-shifted westerly winds in the Southern Hemisphere result in increased residual circulation, greater upwelling of carbon-rich deep waters and oceanic outgassing, which increases atmospheric $\mathrm{pCO}_{2}$ by $\sim 20 \mu \mathrm{atm}$; weaker or southward-shifted winds lead to the opposing result. The ocean carbon inventory in our model varies through contrasting changes in the saturated, disequilibrium and biogenic (soft-tissue and carbonate) reservoirs, each varying by $\mathrm{O}(10-100) \mathrm{PgC}$, all of which contribute to the net anomaly in atmospheric $\mathrm{CO}_{2}$. Increased residual overturning deepens the global pycnocline, warming the upper ocean and decreasing the
\end{abstract}

J. M. Lauderdale $(\bowtie) \cdot$ R. G. Williams

Department of Earth, Ocean and Ecological Sciences,

School of Environmental Science, University of Liverpool,

4 Brownlow Street, Liverpool L69 3GP, UK

e-mail: j.lauderdale@liverpool.ac.uk

A. C. N. Garabato - K. I. C. Oliver

Ocean and Earth Science, National Oceanography Centre, Southampton, University of Southampton Waterfront Campus, European Way, Southampton SO14 3ZH, UK

M. J. Follows

Department of Earth, Atmosphere and Planetary Sciences, Massachusetts Institute of Technology, 77 Massachusetts Avenue, Cambridge, MA, USA saturated carbon reservoir. Increased upwelling of carbonand nutrient-rich deep waters and inefficient biological activity results in subduction of unutilized nutrients into the ocean interior, decreasing the biogenic carbon reservoir of intermediate and mode waters ventilating the Northern Hemisphere, and making the disequilibrium carbon reservoir more positive in the mode waters due to the reduced residence time at the surface. Wind-induced changes in the model carbon inventory are dominated by the response of the global pycnocline, although there is an additional abyssal response when the peak westerly winds change their latitude, altering their proximity to Drake Passage and changing the depth extent of the southward return flow of the overturning: a northward shift of the westerly winds isolates dense isopycnals, allowing biogenic carbon to accumulate in the deep ocean of the Southern Hemisphere, while a southward shift shoals dense isopycnals that outcrop in the Southern Ocean and reduces the biogenic carbon store in the deep ocean.

Keywords Carbon Partitioning - Southern Ocean residual circulation - Southern Hemisphere westerly winds .

Atmospheric carbon dioxide

\section{Introduction}

The Southern Ocean is a unique region where carbon dioxide is both sequestered into the upper ocean and returned from the deep ocean to the atmosphere (Fig. 1). This contrasting pattern of air-sea exchange is partly a response to the action of the winds, which drive surface waters northward as part of the residual overturning circulation across the Antarctic Circumpolar Current (ACC). These surface waters are made more buoyant by atmospheric forcing and subducted along 
sloping isopycnals, forming Subantarctic Mode Waters (SAMW) and Antarctic Intermediate Waters (AAIW). At the same time, wind-induced northward transfer at the surface leads to upwelling of deep waters on the southern flank of the ACC (e.g. Marshall and Speer 2012). This pattern of circulation is reflected in the expected distribution of natural, preindustrial, air-sea carbon dioxide exchange, with oceanic uptake at midlatitudes in regions of strong subduction and oceanic release in regions of upwelling where carbon-rich deep waters return to the surface (Gloor et al. 2003; Mikaloff Fletcher et al. 2007). On the other hand, limited $\mathrm{CO}_{2}$ flux observations suggest widespread uptake over the Southern Ocean, possibly due to anthropogenic $\mathrm{CO}_{2}$ transfer (Takahashi et al. 2002; Gloor et al. 2003).

There are different hypotheses as to how the pattern of natural carbon uptake and outgassing to the atmosphere varies with changes in wind forcing. The motivation for our thought experiments are based on two lines of evidence for the present and the past. In the present day, stronger winds in the Southern Ocean, associated with a stronger polar vortex, are linked to increased outgassing of carbon, due to greater mixing and entrainment of carbon-rich waters into

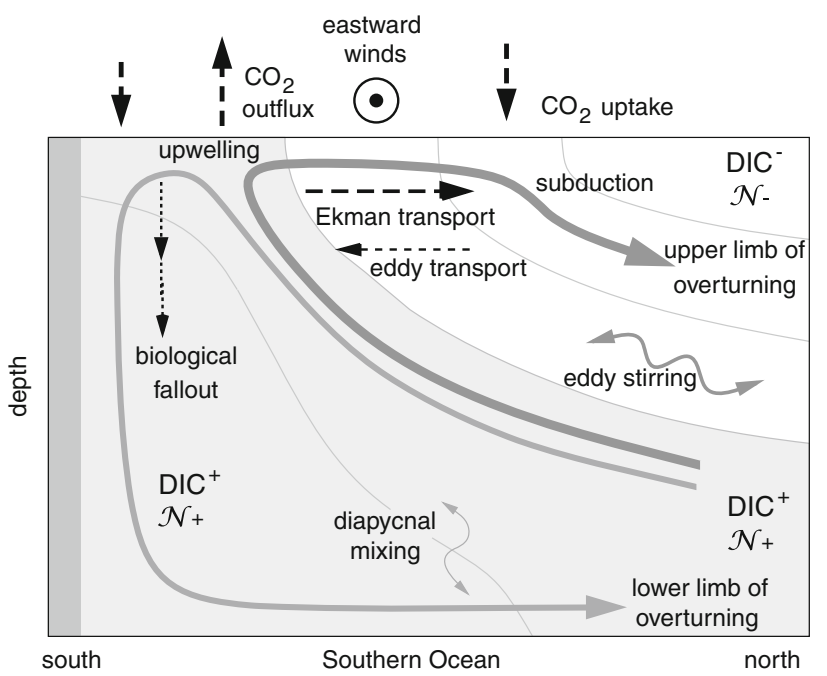

Fig. 1 A schematic depicting the meridional circulation and the carbon cycle in the Southern Ocean. The meridional overturning is made up of a mid-depth influx of dense waters that upwells and are returned via an upper or lower limb (thick grey arrows). The upper limb is part of the residual circulation, where the eastward winds induce a northward Ekman transport and the slumping of density surfaces (thin grey line) lead to an opposing geostrophic eddy transport (black dashed arrows). The nutrient $(\mathcal{N})$ and dissolved inorganic carbon (DIC) have high concentrations at depth from regeneration of biological fallout. Upwelling of carbon-rich waters leads to an outflux of carbon to the atmosphere. Conversely, there is a carbon uptake where mode waters are subducted along the northern flank of the Antarctic Circumpolar Current and also probably where dense bottom waters form at higher latitudes. Redrawn from Williams and Follows (2011) the surface mixed layer on seasonal timescales (Le Quéré et al. 2007, 2008). Stronger winds might at the same time be associated with a longer timescale response of the Southern Ocean residual circulation, with stronger overturning enhancing the subduction of carbon-rich mode waters into the thermocline (e.g. Lenton and Matear 2007). These changes in ocean circulation also increase the upwelling of nutrients to the surface that fuel enhanced biological productivity (Lovenduski and Gruber 2005) potentially counteracting outgassing from upwelled, carbon-rich waters.

In the past, changes in the Southern Ocean residual circulation have been invoked as a way of altering the ocean carbon inventory and, thus, atmospheric $\mathrm{CO}_{2}$ (e.g. Sigman and Boyle 2001; Keeling and Visbeck 2001). For example, increased rates of opal accumulation during the transition from glacial to interglacial climate, linked to greater supply of dissolved silicate in upwelling waters, suggest a reinvigorated Southern Ocean residual circulation after sluggish residual overturning during stadial periods (Anderson et al. 2009). Toggweiler et al. (2006) have proposed that this more vigorous overturning could be achieved by an increase in the strength or a southward shift of the Southern Hemisphere westerlies from a more northward position during glacial maxima, reducing the storage of biogenic carbon in the deep ocean and increasing atmospheric $\mathrm{CO}_{2}$. On the other hand, paleoclimate modeling studies have failed to reconcile these wind stress anomalies with the magnitude or sign of atmospheric $\mathrm{CO}_{2}$ changes. For example, Menviel et al. (2008) simulate moderate changes in Southern Hemisphere wind stress of $\pm 20-30 \%$ associated with \pm 5 ppmv changes in $\mathrm{pCO}_{2}$ due to compensation by export production instigated by the upwelling supply of nutrients, while d'Orgeville et al. (2010) find only minor changes in $\mathrm{pCO}_{2}$ with a latitudinal shift of the westerlies. Tschumi et al. (2008) instead argue that a northward shift of ACC fronts, concurrent with the northward migration of the westerlies during glaciation, might increase dense water outcrop area leading to greater, not reduced, $\mathrm{CO}_{2}$ outgassing. A multi-proxy study from Australasia suggests enhanced westerly winds at the LGM and reduced winds at the start of the Holocene (Shulmeister et al. 2004).

Hence, it is unclear how wind-induced changes in overturning affect the air-sea exchange of carbon both for the present day under a warming climate or in the past, particularly for glacial-interglacial changes. In this study, we conduct a suite of idealized coupled ocean circulation and biogeochemical model experiments with perturbations in the strength and latitude of the westerly winds over the Southern Hemisphere and detail the response of the residual circulation and atmospheric $\mathrm{CO}_{2}$ (Sect. 2). To determine how variations in the partitioning of carbon 
between the atmosphere and ocean are controlled in these experiments, changes in the ocean carbon inventory are diagnosed using a carbon partitioning framework (Ito and Follows 2005; Williams and Follows 2011), defining saturated, biogenic (soft-tissue and carbonate) and disequilibrium carbon reservoirs (Sect. 3).

Our key findings are: (1) atmospheric $\mathrm{CO}_{2}$ is strongly correlated to the residual circulation in our coarse-resolution model experiments; (2) the pycnocline plays a key role in $\mathrm{CO}_{2}$ uptake and outgassing; (3) the moderate net change in atmospheric $\mathrm{CO}_{2}$ results from the interplay between larger anomalies in the saturated, disequilibrium, soft-tissue and carbonate pools between the upper ocean and the abyss and (4) this interplay depends on the strength and latitude of the Southern Hemisphere westerly winds.

Our thought experiments are designed to provide insight into the ocean mechanisms affecting atmospheric $\mathrm{CO}_{2}$, focussing on idealized wind-driven changes with only modest accompanying buoyancy changes, rather than attempting to recreate conditions in the past. Our experiments highlight the complex interplay of carbon reservoirs influenced by wind-induced changes in ocean circulation, nutrient redistribution, biological activity and air-sea exchange.

\section{Southern Ocean model experiments}

\subsection{Model configuration}

To investigate the effect of the residual circulation on the ocean carbon inventory, a global configuration of the MIT general circulation and biogeochemistry model is employed (Marshall et al. 1997) with a horizontal resolution of $2.8^{\circ} \times 2.8^{\circ}$ and 15 non-uniform vertical levels. The model is forced by a 12-month cycle of heat and freshwater fluxes, in some cases with additional relaxation toward climatological sea surface temperature and salinity (Jiang et al. 1999) with timescales of 60 and 90 days, respectively. Monthly winds (Fig. 2a) are from ECMWF (Trenberth et al. 1989). The mesoscale eddy field is parameterized using the Gent and McWilliams (1990) scheme with a constant isopycnal thickness diffusivity of $1 \times 10^{3} \mathrm{~m}^{2} \mathrm{~s}^{-1}$ and interior mixing by a diapycnal diffusivity of $5 \times 10^{-5} \mathrm{~m}^{2} \mathrm{~s}^{-1}$.

The physical model is coupled to an online biogeochemistry model (Dutkiewicz et al. 2005; Parekh et al. $2005)$ that includes the coupled cycles of dissolved inorganic carbon (DIC), alkalinity $\left(\mathrm{A}^{T}\right)$, organic and inorganic phosphorus (DOP and $\mathrm{PO}_{4}$ ), oxygen $\left(\mathrm{O}_{2}\right)$ and dissolved iron (Parekh et al. 2005, 2006) with prescribed monthly aeolian iron deposition (Mahowald et al. 2006). The biologically-mediated transformations of the different elements are related using the fixed stoichiometric ratios of $R_{[C: N: P: O]}=117: 16: 1:-170$ (Anderson and Sarmiento 1994) with a prescribed inorganic to organic rain ratio of $7 \%$. Local equilibrium carbonate chemistry is solved explicitly (Follows et al. 2006) with air-sea fluxes dependent on the square of local wind speed (Wanninkhof 1992). The atmosphere is represented as a simple well mixed carbon reservoir (e.g. Parekh et al. 2006), allowing atmospheric $\mathrm{CO}_{2}$ to be solved for according to net global air-sea fluxes. The ocean-atmosphere carbon pool is assumed to be conserved so that riverine sources and sediment interaction are not included. Hence we assume a closed atmosphereocean carbon system, ignoring sediment interaction and weathering. Archer et al. (2000), Ridgwell and Zeebe (2005) and Chikamoto et al. (2008) address the effect of carbonate compensation processes that occur in an open carbon system over many millennia.

Further details about model configuration and spin-up are given by Lauderdale (2010). In addition, the surface concentrations of DIC and $\mathrm{A}^{T}$ are sensitive to a "virtual flux", $C^{v f l u x}$, due to the use of relaxing surface boundary conditions in which freshwater fluxes are parameterized as a flux of salt (e.g. McKinley et al. 2004). To avoid artificial loss or gain of DIC as the ocean loses or gains salt by relaxation we impose global balance to the virtual flux term by subtracting the mean salinity relaxation flux, which then closes the freshwater budget and provides near conservation for the combined ocean-atmosphere store of carbon.

\subsection{Ensemble of model experiments}

An ensemble of idealized Southern Hemisphere perturbation experiments (see Fig. 2b) are performed. The model is integrated until there is no significant drift in mean temperature, salinity or biogeochemical concentrations and the air-sea flux of carbon approaches zero, usually reached after $\sim 5,000$ years with the majority of the adjustment occurring in the first millennium. Different westerly wind stress changes and different choices for surface buoyancy forcing and mesoscale eddy activity are made:

1. Strength of the peak Southern Hemisphere westerly wind stress is perturbed by $\pm 50 \%$ (e.g. Parekh et al. 2006; e.g. Toggweiler et al. 2006). These experiments (red circles in Fig. 2b, filled for increased winds and open for decreased winds) result in the largest anomalies of Southern Ocean residual circulation of $\sim 10 \mathrm{~Sv}$ and atmospheric $\mathrm{CO}_{2}$ of $\sim 15-20 \mu \mathrm{atm}$ for single perturbations, with stronger winds increasing the residual circulation and raising $\mathrm{pCO}_{2}$.

2. The latitude of peak westerlies is displaced $\pm 10^{\circ}$, keeping the zonally averaged wind strength the same as the control (red triangles in Fig. $2 b$ pointing in the 


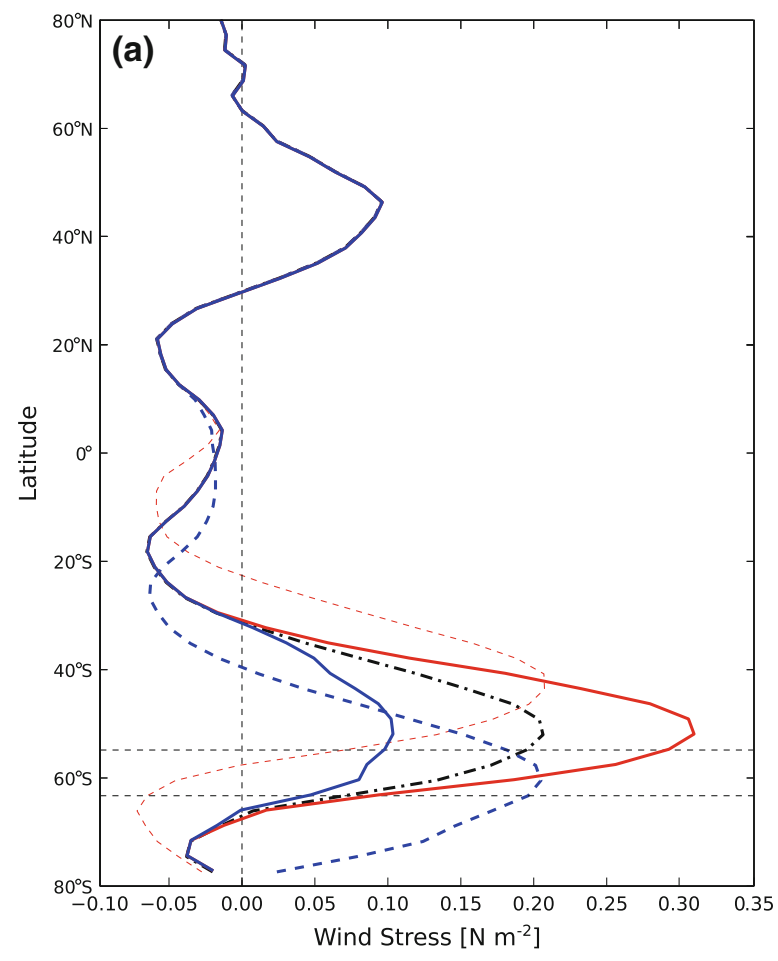

Fig. 2 a Zonally-averaged zonal wind-stresses used to force altered Southern Ocean residual circulation: the control wind profile (dashed line with dot) and the perturbations with the magnitude of the westerlies increased (solid line) and decreased (solid line) by $50 \%$ and the peak wind-stress in the Southern Ocean migrated nominally $10^{\circ}$ north (dashed line) and south (dashed line); see also Table 1 . The
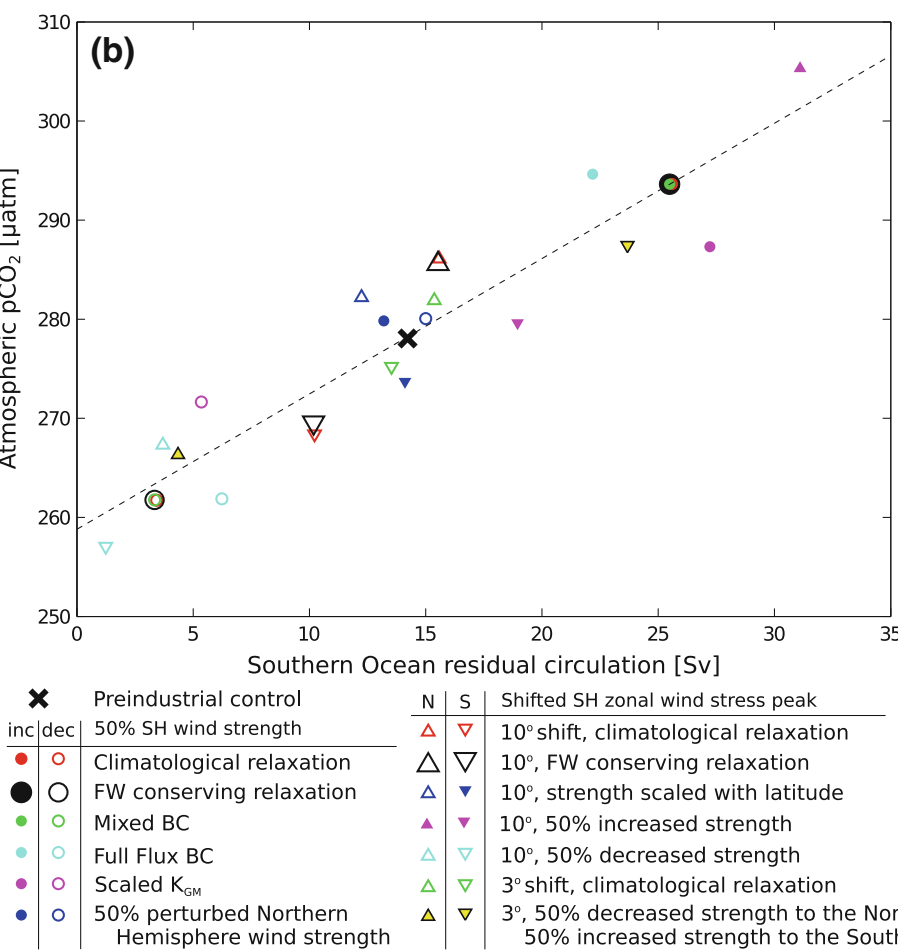

$$
\begin{array}{l|l|l}
\mathrm{N} & \mathrm{S} & \text { Shifted SH zonal wind stress peak } \\
\hline \Delta & \nabla & 10^{\circ} \text { shift, climatological relaxation } \\
\Delta & \nabla & 10^{\circ}, \mathrm{FW} \text { conserving relaxation } \\
\Delta & \nabla & 10^{\circ}, \text { strength scaled with latitude } \\
\Delta & \nabla & 10^{\circ}, 50 \% \text { increased strength } \\
\Delta & \nabla & 10^{\circ}, 50 \% \text { decreased strength } \\
\Delta & \nabla & 3^{\circ} \text { shift, climatological relaxation } \\
\Delta & \nabla & 3^{\circ}, 50 \% \text { decreased strength to the North, } \\
& & 50 \% \text { increased strength to the South }
\end{array}
$$

location of Drake Passage $\left(\sim 55^{\circ}-63^{\circ}\right)$ is indicated by horizontal dashed lines. b Scatter plot of Southern Ocean residual circulation (maximum streamfunction below $500 \mathrm{~m}$ ) against atmospheric $\mathrm{pCO}_{2}$ for the ensemble of 27 perturbation experiments described in Sect. 2.2 $\left(\mathrm{R}^{2}=0.89\right)$. The larger black symbols indicate the locations of the control run and the four principal experiments presented in this study

cardinal direction of the shift). This magnitude of shift was suggested by proxies that track the migration of cool, wet conditions under the westerly storm tracks in South America and associated abundance of indicative flora assemblages over glacial-interglacial transitions (Moreno et al. 1999; McCulloch et al. 2000; Toggweiler et al. 2006, and references therein). These perturbations result in anomalies of residual circulation of $\sim 5 \mathrm{~Sv}$ and $\mathrm{pCO}_{2}$ of 7-10 $\mu \mathrm{atm}$, roughly half as large as the wind stress magnitude changes, with northwardshifted winds causing more vigorous Southern Ocean residual circulation and elevated atmospheric $\mathrm{CO}_{2}$.

3. A further latitudinal shift of the westerlies is executed where the displacement is motivated by varied results from paleoclimate models that generally suggest more subdued changes in Southern Ocean winds (e.g. Menviel et al. 2008; Rojas et al. 2009; Chavaillaz et al. 2012). Modern simulations using coupled climate models (e.g. Saenko et al. 2005; Russell et al. 2006a, b) and 25 years of observations of the Southern Ocean winds under climatic warming (e.g. Huang et al. 2006) support this, indicating $\pm 3^{\circ}$ is a more realistic upper bound for Southern Ocean wind stress migration. When forced by these winds (open green

triangles in Fig. 2b), our model produces anomalies that are roughly a third of those produced by $\pm 10^{\circ}$ shifts, with residual circulation changing by $\sim 4 \mathrm{~Sv}$ and $\mathrm{pCO}_{2}$ changing by $\sim 4 \mu \mathrm{atm}$. Again, northwardshifted winds increase Southern Ocean circulation and atmospheric $\mathrm{CO}_{2}$.

4. Composite perturbations are also performed where both the magnitude and peak latitude is altered to allow the extent of linear superposition of our individual perturbations described above to be assessed. In Fig. $2 b,+50 \%$ strength with $\mathrm{a} \pm 10^{\circ}$ shift are filled magenta triangles; $-50 \%$ strength with $\mathrm{a} \pm 10^{\circ}$ shift are open cyan triangles; filled yellow triangles plot a $50 \%$ decrease in strength for $3^{\circ}$ northward-shifted winds and $50 \%$ increase in strength for $3^{\circ}$ southward-shift. The latter of these perturbations again resemble more realistic conditions (e.g. Huang et al. 2006). Furthermore, the effect of fundamentals such as conservation of angular momentum of the westerlies may also be investigated by scaling wind stress magnitude by the length of peak latitude circle. Integrating the stronger winds $(\sim 20 \%)$ used in the scaled southward-shifted wind stress perturbation (filled dark blue triangle in Fig. 2b) around a smaller 
latitude band $(\sim 4,500 \mathrm{~km}$ shorter than the control) returns the same value as integrating the weaker winds used in the scaled northward-shifted wind stress perturbation (open dark blue triangles in Fig. 2b) around the $\sim 3500 \mathrm{~km}$ longer latitude circle compared to the control. These experiments return a wide range of circulation and $\mathrm{pCO}_{2}$ anomalies and demonstrate that linear combination of wind strength and peak latitude perturbations appears to occur to a reasonable degree. The effects of magnitude changes dominates anomalies due to wind shifts.

5. The Gent and McWilliams (1990) isopycnal thickness diffusion coefficient is scaled by wind stress magnitude (by about $50 \%$, Fyfe et al. 2007; Zickfeld et al. 2007) increasing parameterized mesoscale eddy activity for stronger winds and reducing parameterized eddy activity for weaker winds (magenta circles in Fig. 2b). In these cases, residual circulation anomalies are largely unchanged while atmospheric $\mathrm{CO}_{2}$ anomalies are reduced by $5-10 \mu \mathrm{atm}$ compared to the initial wind strength perturbations.

6. We address the sensitivity of our results to surface buoyancy boundary conditions using different combinations of fixed surface fluxes and relaxation to climatology. The experiments above were all run with prescribed heat and freshwater fluxes with additional climatological relaxation to surface temperature and salinity ("climatological relaxation" in Fig. 2b, or type II boundary conditions, c.f. Jiang et al. 1999). Secondly, as detailed in Sect. 2.1, salinity relaxation introduces artificial loss or gain of DIC, the virtual flux, as surface salinity is relaxed towards observations. By balancing salinity relaxation, the outcome is a net freshwater-conserving buoyancy boundary condition ("FW conserving" in Fig. 2b), which is used to integrate the initial $50 \%$ magnitude and $10^{\circ}$ latitude wind perturbations (with surface temperature relaxation, larger black circles and triangles in Fig. 2b). The results essentially lead to the same anomalies of Southern Ocean residual circulation and atmospheric $\mathrm{CO}_{2}$. Thirdly, we rerun the wind stress magnitude perturbations with a flux-only boundary condition for freshwater, prescribing an annual cycle of monthly freshwater fluxes derived from the equilibrated control run ("mixed BC", maintaining temperature relaxation). With changes in Southern Hemisphere wind strength (green circles in Fig. 2b), similar anomalies in residual circulation and atmospheric $\mathrm{CO}_{2}$ as the previous two schemes are achieved. Lastly, control heat and freshwater fluxes are prescribed ("full flux BC", cyan circles in Fig. 2b). Again, with changes in Southern Hemisphere wind strength, $\sim 5 \mathrm{~Sv}$ smaller anomalies in residual circulation are obtained, driven by diapycnal and eddy buoyancy fluxes in the mixed layer, but little overall change in the anomalies for atmospheric $\mathrm{CO}_{2}$.

Unfortunately, when integrated with the flux-only boundary condition for salt, experiments with northor southward-shifted winds resulted in significant reorganization of the North Atlantic meridional overturning circulation, which itself impacts atmospheric $\mathrm{CO}_{2}$ (e.g. Chikamoto et al. 2008). These experiments are not included in our model suite as the focus of this study is Southern Ocean wind-driven changes in the ocean carbon inventory. There is a wider question as to whether the fixed salt fluxes derived from the control steady state would be appropriate for shifted winds as one might expect concurrent migration of regions of freshwater loss or gain over the Southern Ocean with migrated westerlies (e.g. Dong and Valdes 1998).

7. Finally, $50 \%$ perturbations to the Northern Hemisphere westerly winds are performed to confirm anomalies in atmospheric $\mathrm{CO}_{2}$ and residual circulation were not due to remotely forced changes in the carbon cycle outside of the Southern Ocean (dark blue circles in Fig. 2b). Only minor differences between these experiments and the control were found, therefore the majority of the results presented here are attributable to altered forcing in the Southern Hemisphere.

Across the whole model suite of 27 steady-state integrations, atmospheric $\mathrm{pCO}_{2}$ varies between 257 and $304 \mu \mathrm{atm}$ (Fig. 2b; Table 1) and there is an overall positive correlation $\left(\mathrm{R}^{2}=0.89\right)$ with the overturning in the Southern Ocean, as measured by the residual circulation below $500 \mathrm{~m}$.

To understand this connection between Southern Ocean residual circulation and atmospheric $\mathrm{CO}_{2}$ in our model, we next consider the physical changes in circulation and the ocean carbon cycle in a subset of our experiments. Our four principal experiments have $50 \%$ increased and decreased wind stress magnitude and $10^{\circ}$ north- and south-shifted winds, standard model parameters and freshwater-conserving boundary conditions.

\subsection{Physical response of the Southern Ocean residual circulation and global pycnocline}

Net overturning in the Southern Ocean is diagnosed by applying residual-mean theory (e.g. Marshall et al. 1997; Karsten and Marshall 2002; Marshall and Radko 2003), combining the wind-induced Eulerian-mean and eddydriven circulations to give the residual circulation. The residual transport streamfunction, $\psi^{\text {res }}$, is defined by the maximum value below $500 \mathrm{~m}$ depth in the Southern Hemisphere. In our principal experiments, enhanced Southern Ocean wind-stress increases northward transport 
Table 1 Initial response of the model to altered Southern Ocean ventilation, driven by perturbations in the magnitude (Peak $\tau_{x}$ ) and latitude of the Southern Hemisphere westerly winds in Fig. 2

\begin{tabular}{lccccc}
\hline Expt & Control & \multicolumn{1}{l}{ Inc } & Dec & $\begin{array}{c}\text { North- } \\
\text { shifted }\end{array}$ & $\begin{array}{c}\text { South- } \\
\text { shifted }\end{array}$ \\
\hline Peak $\tau_{x}\left(\mathrm{Nm}^{-2}\right)$ & 0.21 & 0.31 & 0.11 & 0.21 & 0.21 \\
Latitude $\left(^{\circ}\right)$ & -52.0 & -52.0 & -52.0 & -43.6 & -60.5 \\
$\mathrm{pCO}_{2}(\mu \mathrm{atm})$ & 278.1 & 293.6 & 261.8 & 285.7 & 269.4 \\
$\psi^{\text {Eul }}(\mathrm{Sv})$ & 40.9 & 61.0 & 21.0 & 50.6 & 33.1 \\
$\psi^{\text {eddy }}(\mathrm{Sv})$ & -28.4 & -38.1 & -22.0 & -29.0 & -28.3 \\
$\psi^{\text {res }}(\mathrm{Sv})$ & 14.2 & 25.5 & 3.3 & 15.5 & 10.2 \\
$\mathrm{~W}(\mathrm{TW})$ & 0.83 & 1.36 & 0.44 & 1.01 & 0.46 \\
$\Delta \mathrm{BP}\left(\mathrm{PgC}{ }^{-1}\right)$ & 0 & 0.6 & -0.1 & -0.3 & 0.1 \\
$P^{*}(\%)$ & 35.7 & 33.0 & 38.3 & 35.4 & 33.4
\end{tabular}

The surface forcing drives anomalies in atmospheric $\mathrm{pCO}_{2}$ through changes in the wind-driven Eulerian-mean $\left(\psi^{E u l}\right)$ and parameterized eddy $\left(\psi^{e d d y}\right)$ circulations that partially compensate to form the Southern Ocean residual circulation $\left(\psi^{\text {res }}\right.$, maximum value below 500 $\mathrm{m})$ driven by the globally integrated work done by the winds on the surface geostrophic circulation (W, see Lauderdale et al. 2012). Altered circulation affects nutrient distributions, leading to small anomalies in net biological production $(\triangle \mathrm{BP})$ and efficiency of the soft tissue pump [ $P^{*}$, Ito and Follows (2005)]

across $50^{\circ} \mathrm{S}$ in the Ekman layer and strengthens the Eulerian-mean circulation by $50 \%\left(\psi^{E u l}\right.$, Table 1$)$, resulting in increased isopycnal tilt (Fig. 3a). The increase in baroclinicity enhances parameterized mesoscale eddy activity by $\sim 35 \%\left(\psi^{e d d y}\right.$, Table 1$)$, which in turn acts to flatten isopycnals and partially compensates for the increased Eulerian-mean flow, resulting in a smaller increase of the residual overturning (Fig. 4a). Decreased wind-stress leads to the opposite response, with reduced Ekman transport and Eulerian-mean overturning causing a flattening of Southern Ocean isopycnals (Fig. 3b), reduced baroclinicity, suppression of parameterized mesoscale eddy activity and a weakening of the residual circulation (Fig. 4b). The maximum changes in $\psi^{E u l}$ and $\psi^{e d d y}$ act over slightly different spatial regions, so do not directly compensate to give the maximum change in $\psi^{\text {res }}$ in Table 1.

Northward shifted winds with peak values held at the same magnitude as the control (Fig. 2a) lead to a stronger residual circulation (Fig. 4c). Northward Ekman transport is enhanced due to a reduction in Coriolis parameter at lower latitudes and there is decreased correspondence between Eulerian-mean and eddy circulations, as well as a geometric increase in the longitudinal width of the ocean towards the equator that further increases northward Ekman transport through greater zonally-integrated stress. The vertical extent of the Southern Ocean overturning cell is significantly shallower due to the reduced coincidence between the westerlies and Drake Passage $\left(55^{\circ}-63^{\circ} \mathrm{S}\right)$, which relaxes the dynamical constraint for the wind-driven transport to be returned below the depth of the sill in the zonally-unbounded latitude band (e.g. Gill and Bryan 1971). Similarly, southward-shifted winds have a weaker residual circulation (Fig. 4d) due to a larger Coriolis parameter at high latitudes, smaller latitude circle at which the strongest winds are located and closer correspondence between the Eulerian-mean and eddy circulations. The closer alignment between the winds and unblocked latitudes of Drake Passage ensures the deep return flow of the overturning circulation is maintained.

Changes in Southern Ocean residual circulation globally modify the interior density structure of the upper ocean. When the winds are increased or shifted north (Fig. 3a, c), ventilation of intermediate and mode waters increases with a deepening of low latitude isopycnals. A reduction or southward shift of the westerlies decreases the rate of mode and intermediate water formation causing shoaling of the low latitude pycnocline (Fig. 3b, d). The deep density field is also modified with dense waters more strongly upwelled south of $\sim 40^{\circ} \mathrm{S}$ under increased winds and, conversely, more weakly upwelled under decreased winds. When the westerlies are shifted north, the shallower residual cell and northward migration of the regions of Ekman divergence leads to significant slumping and isolation of isopycnals south of $40^{\circ} \mathrm{S}$ (Fig. 3c). A significant increase in dense water outcropping to the south of $40^{\circ} \mathrm{S}$ occurs when the westerlies are moved south due to a deep residual circulation and more southern regions of Ekman divergence (Fig. 3d).

These physical changes in density and the residual circulation are associated with moderate changes in atmospheric $\mathrm{CO}_{2}$ of $\pm 20 \mu \mathrm{atm}$ (Fig. 2b) in which stronger residual circulation is associated with higher atmospheric $\mathrm{CO}_{2}\left(\mathrm{R}^{2}=0.89\right)$. In the next section we explore how changes in atmospheric $\mathrm{CO}_{2}$ are achieved by considering anomalies in the ocean carbon inventory using a carbon partitioning framework.

\section{Modeled carbon system response to Southern Ocean circulation}

\subsection{Distribution of DIC in the model experiments}

The distribution of DIC in the control integration (Fig. 5a, b) broadly resembles observations with low concentrations at the surface in the subtropical gyres and newly formed deep waters in the North Atlantic, increasing concentrations in the Southern Hemisphere and other upwelling regions, and the highest concentrations in the oldest deep waters of the North Pacific. Zonally-averaged anomalies of DIC for different wind experiments (Fig. 5c-f) reveal a complex spatial pattern of changes. Most importantly, 

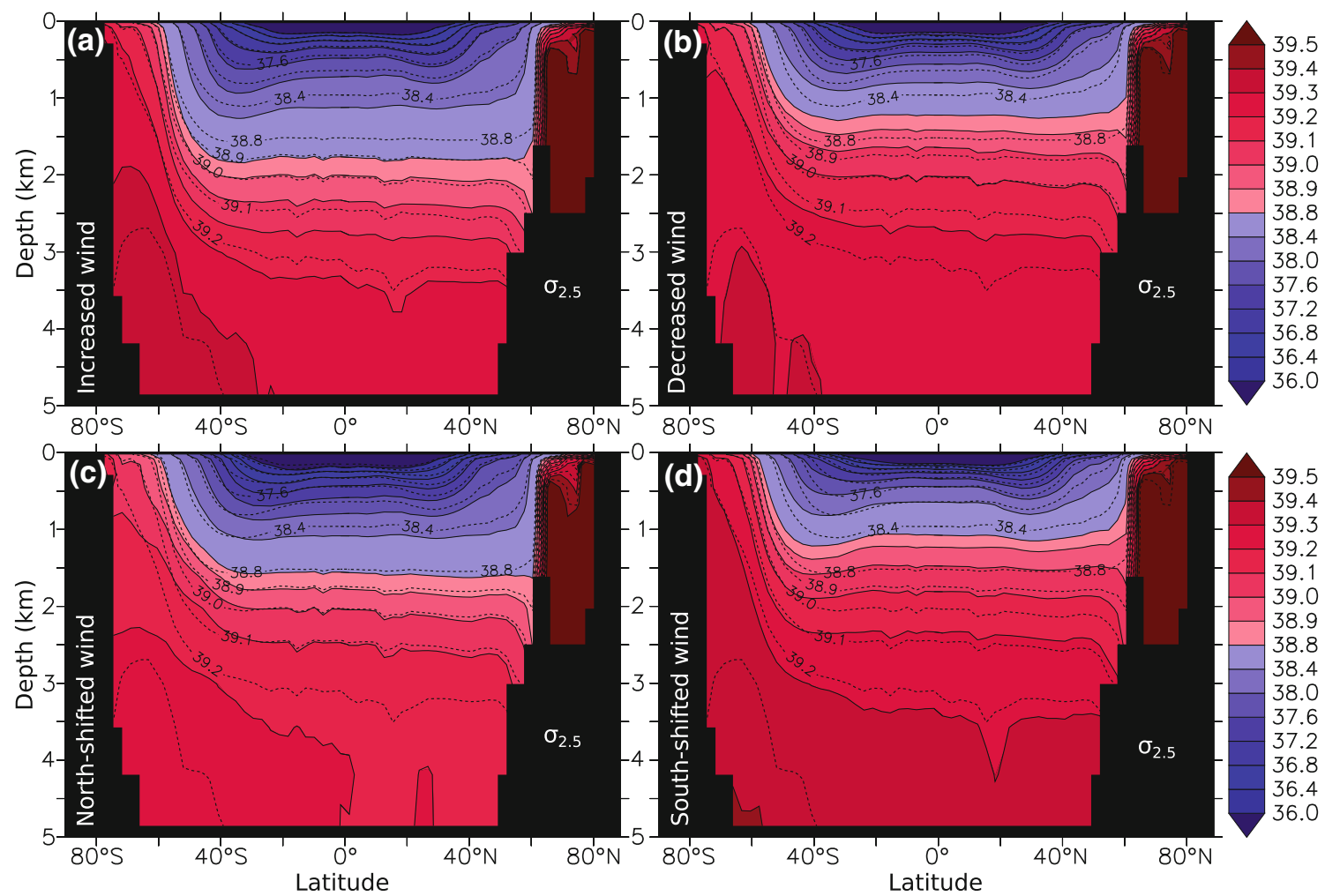

Fig. 3 Zonally-averaged sections of potential density, $\sigma_{2.5}\left(\mathrm{~kg} \mathrm{~m}^{-3}\right)$ for a increased, $\mathbf{b}$ decreased, $\mathbf{c}$ northward-shifted and $\mathbf{d}$ southwardshifted westerly winds with the control density field overlaid as

dashed contours. The uneven contour scale switches from blue to red at the density level 38.8, illustrating the changing depth of the low latitude pycnocline

the water masses (Follows et al. 2002; DeVries and Primeau 2009).

changes in the intermediate waters between 500-1500 $\mathrm{m}$ in our model appear to determine the sign of the change in atmospheric $\mathrm{CO}_{2}$, with decreased DIC concentration when atmospheric $\mathrm{CO}_{2}$ is elevated and increased DIC when atmospheric $\mathrm{CO}_{2}$ is reduced. Opposing sign anomalies in DIC appear in the deep ocean.

The biological production (BP, Table 1) is not driving the atmospheric $\mathrm{CO}_{2}$ changes, but instead is responding to altered nutrient supply by the residual circulation resulting in elevated production when atmospheric $\mathrm{CO}_{2}$ is high and reduced production when atmospheric $\mathrm{CO}_{2}$ is low, consistent with the compensatory mechanism of Menviel et al. (2008).

These DIC anomalies have a similar character as obtained in other general circulation models forced by altered Southern Hemisphere westerly winds (Marinov et al. 2008; Tschumi et al. 2008; d'Orgeville et al. 2010; Kwon et al. 2011), particularly with respect to DIC anomalies at intermediate depths. The paradigm of wind control of the deep ocean carbon inventory has largely been based on box model studies (e.g. Sarmiento and Toggweiler 1984; Siegenthaler and Wenk 1984; Knox and McElroy 1984). However, comparisons between these simple models and more complex box model configurations and prognostic ocean circulation models demonstrates the importance of resolving the vertical structure of

\subsection{Partitioning of the ocean carbon cycle}

The processes controlling these DIC anomalies are now diagnosed using a carbon partitioning framework (Brewer 1978; Chen and Millero 1979; Gruber et al. 1996; Ito and Follows 2005; Williams and Follows 2011). The in situ concentration of DIC $\left(\mathrm{C}^{D I C}\right)$ is decomposed into saturated, $\mathrm{C}^{\text {sat }}$, soft-tissue, $\mathrm{C}^{\text {soft }}$, carbonate, $\mathrm{C}^{\text {carb }}$, and disequilibrium, $\mathrm{C}^{\text {dis }}$, components,

$C^{D I C}=C^{s a t}+C^{s o f t}+C^{c a r b}+C^{d i s}$.

The change in saturated reservoir, $\mathrm{C}^{\text {sat }}$, is further split depending on changes in the potential temperature, salinity and preformed alkalinity of the ocean, $\Delta \mathrm{C}^{\text {sat }}\left(\theta, \mathrm{S}, \mathrm{A}^{\text {pre }}\right)$, and changes in atmospheric $\mathrm{CO}_{2}, \Delta \mathrm{C}^{\text {sat }}\left(\mathrm{pCO}_{2}\right)$. The latter component provides a negative feedback on the ocean carbon inventory (Goodwin and Lenton 2009). $\mathrm{C}^{\text {soft }}$ and $\mathrm{C}^{\text {carb }}$ depend on the biological production and remineralization of sinking organic and inorganic carbon, while the disequilibrium pool, $\mathrm{C}^{\text {dis }}$, is diagnosed as the residual concentration of the other components. This disequilibrium occurs due to the timescale for $\mathrm{CO}_{2}$ exchange with the atmosphere, which is typically one 

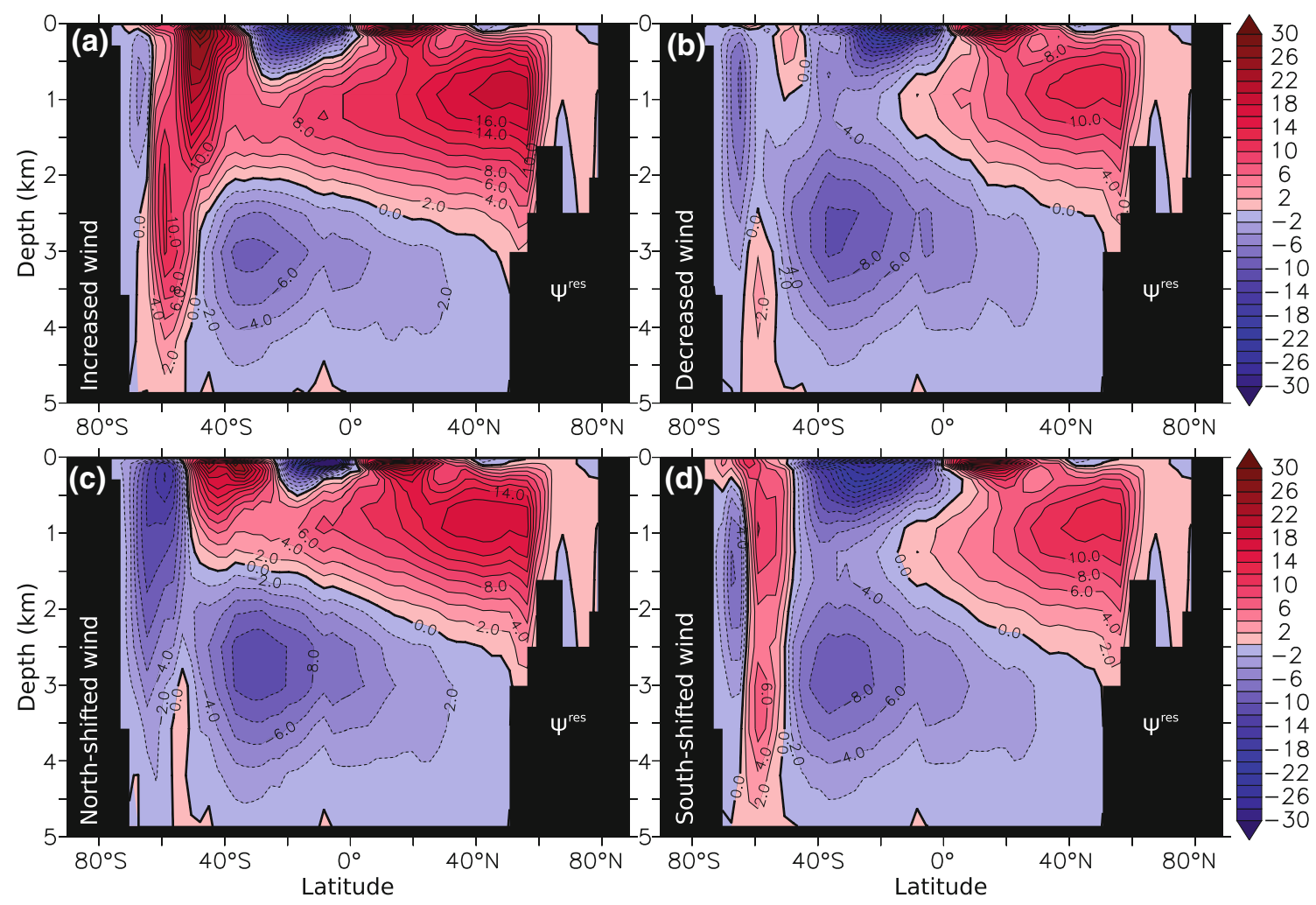

Fig. 4 Zonally-averaged sections of the residual overturning circulation ( $\left.\psi^{\text {res }}, \mathrm{Sv}\right)$, which includes both wind- and parameterized eddy-induced flows for a increased, $\mathbf{b}$ decreased, $\mathbf{c}$ northward-shifted and $\mathbf{d}$ southward-shifted westerly winds

year, being of the same order as the residence time of a water parcel at the sea surface (Ito et al. 2004b). The methodology for evaluating each reservoir is given in the "Appendix".

\subsection{Carbon partitioning in the model experiments}

The carbon framework is now applied to the model experiments, presenting in situ concentrations for the control run, anomalies for $\mathrm{C}^{\text {sat }}, \mathrm{C}^{\text {soft }}$ and $\mathrm{C}^{\text {carb }}$, and both in situ and anomalous concentrations for $\mathrm{C}^{\text {dis }}$.

\subsection{Initial constituents from the control run}

The in situ concentration for the saturated reservoir, $\mathrm{C}^{\text {sat }}$, is responsible for a large proportion of the overall DIC concentration (Fig. 6a, b) and has low values in the warm upper ocean and high values in the cold dense waters, with distributions that are similar in both the Atlantic and Indopacific basins. The soft tissue reservoir, $\mathrm{C}^{\text {soft }}$, linked to the formation and remineralization of organic matter, shows considerable spatial variability, again reflected in the DIC distribution (Fig. 6c, d) due to water-mass age and the progressive accumulation of regenerated carbon and nutrients. Newly ventilated waters in the Southern Ocean and North Atlantic have low values of $\mathrm{C}^{\text {soft }}$, whereas older water masses in the North Pacific have high values due to accumulation of sinking organic material.

The carbonate reservoir, $\mathrm{C}^{\mathrm{carb}}$, measures biogenic formation and dissolution of calcium carbonate, and is relatively small compared to $\mathrm{C}^{\text {sat }}$ and $\mathrm{C}^{\text {soft }}$. Although the distributions of $\mathrm{C}^{\text {soft }}$ and $\mathrm{C}^{\text {carb }}$ are broadly similar, hard tissue has a greater depth for remineralization than soft tissue (Fig. 6e, f). Elevated values of $\mathrm{C}^{\text {soft }}$ and $\mathrm{C}^{\mathrm{carb}}$ at the seafloor, particularly noticeable in the Atlantic may be the result of the absence of interactive sediments in this model; organic particles are immediately remineralized on reaching the seafloor.

Lastly, the disequilibrium component, $\mathrm{C}^{\text {dis }}$, shows the smallest contribution to DIC and is slightly negative throughout most of the ocean, reflecting an undersaturation associated with cooling and rapid subduction of water masses in the North Atlantic and Southern Ocean (Fig. 6f, g). Slight oversaturation instead exists in the upper parts of the surface Southern Ocean, North Indian Ocean and the North Pacific from upwelling of carbon-rich deep waters, as well as warming as these upwelled waters are transported equatorward in the Ekman layer. In the mid-depths of the North Pacific there is also a spurious positive signal for $\mathrm{C}^{\text {dis }}$ representing an accumulated error from overestimating $\mathrm{C}^{\text {soft }}$ from apparent oxygen utilization (AOU, see the "Appendix"). Nonetheless, the distribution and 

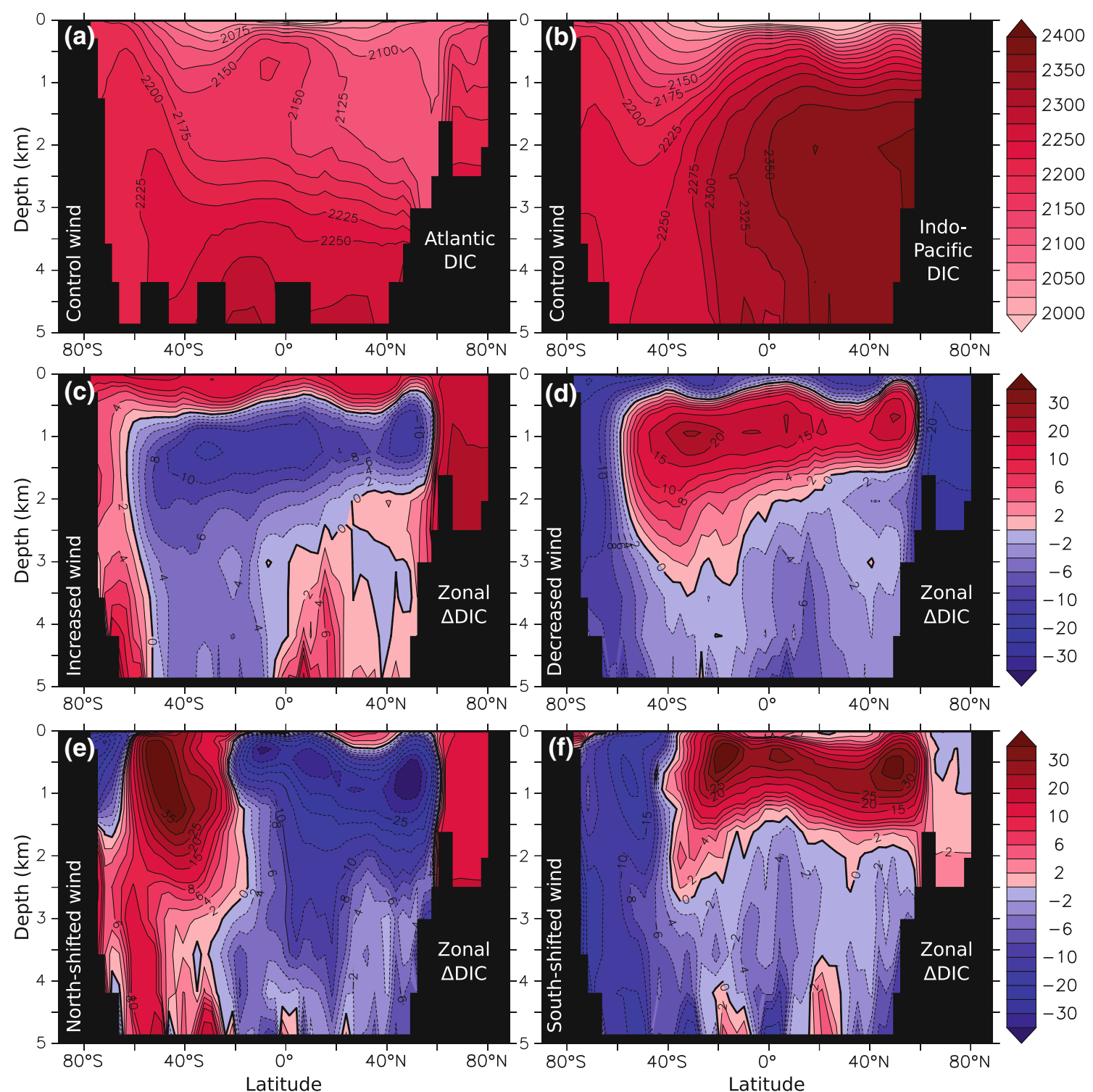

Fig. 5 DIC concentration $\left(\mathrm{mmol} \mathrm{m}^{-3}\right.$ ) for the control run in a) the Atlantic and $\mathbf{b}$ the IndoPacific and Zonally-averaged DIC anomalies (mmol $\mathrm{m}^{-3}$ ) for $\mathbf{c}$ increased, $\mathbf{d}$ decreased, e northward-shifted and $\mathbf{f}$ southward-shifted westerly winds

concentration of carbon components in the control run are strikingly similar to a data-based evaluation reported by Williams and Follows (2011).

We now consider the anomalies in each of these reservoirs when the Southern Hemisphere winds are perturbed. A small residual error remains when the carbon system anomalies in Table 2 are combined, with a mean value of only $-0.5 \mathrm{PgC}$, which is one or two orders of magnitude smaller than the other anomalies. This error is probably due to the formulation of surface flux routines, such as using uniform density when converting from mass to volume units and using globally-averaged values of salinity and carbon in calculating the virtual fluxes, as well as remaining imbalance in the surface freshwater/salt fluxes themselves.

\subsubsection{Anomaly of the saturated DIC concentration, $\Delta \mathrm{C}^{\text {sat }}$}

The relationship between atmospheric $\mathrm{CO}_{2}$ and $\Delta \mathrm{C}^{\text {sat }}\left(\mathrm{pCO}_{2}\right)$, the change in globally-integrated carbon content in the saturated reservoir with $\mathrm{pCO}_{2}$ at the temperature, salinity and preformed alkalinity of the control integration is nearly linear over the range of atmospheric $\mathrm{CO}_{2}$ considered here (Fig. 7). This relationship supports the linearization necessary to separate $\Delta \mathrm{C}^{\text {sat }}$ (see A.4), although the buffering effect becomes noticeable at values greater than $\sim 400 \mu \mathrm{atm}$. As the $\mathrm{pCO}_{2}$ of the atmosphere changes, integrated $\Delta \mathrm{C}^{\text {sat }}\left(\mathrm{pCO}_{2}\right)$ instantly adjusts with a sensitivity of $8.5{\mathrm{PgC} \mu \mathrm{atm}^{-1}}^{-1}$ (Fig. 7), acting as a negative feedback on other ocean carbon reservoir changes. 

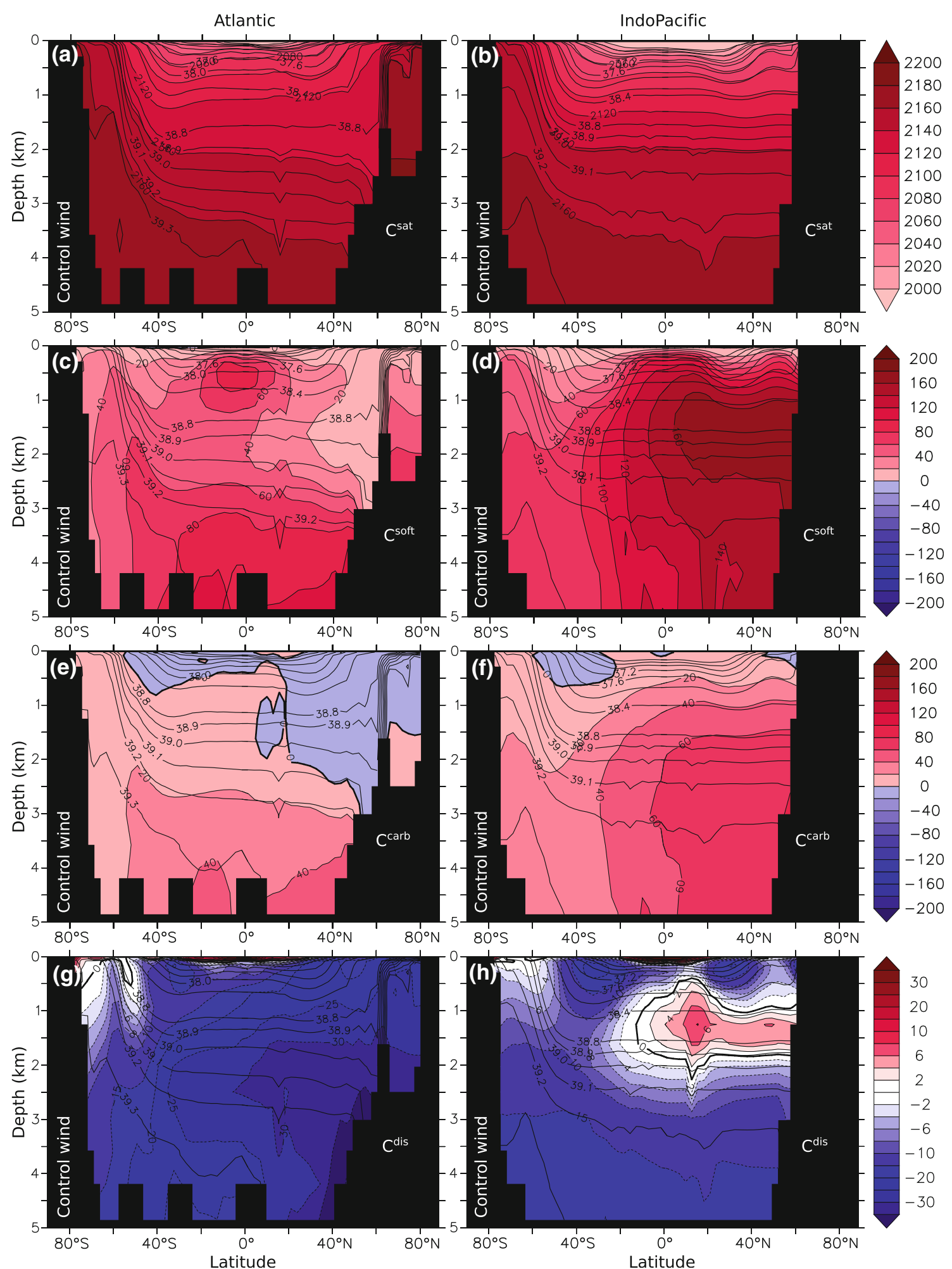

Fig. 6 Zonally-averaged concentrations for the control simulation $\left(\mathrm{mmol} \mathrm{m}^{-3}\right)$ in the Atlantic (left column) and Indopacific (right column) of the carbon components for $(\mathbf{a}, \mathbf{b}) \mathrm{C}^{\text {sat }},(\mathbf{c}, \mathbf{d}) \mathrm{C}^{s o f t},(\mathbf{e}, \mathbf{f}) \mathrm{C}^{\mathrm{carb}}$ and $(\mathbf{g}, \mathbf{h}) \mathrm{C}^{\text {dis }} . \sigma_{2.5}$ density contours are overlaid in each case

Anomalies of $\mathrm{C}^{\text {sat }}\left(\theta, \mathrm{S}, \mathrm{A}^{\text {pre }}\right)$, the saturated DIC concentration at the fixed atmospheric $\mathrm{pCO}_{2}$ of the control integration with perturbed potential temperature, salinity and preformed alkalinity (Fig. 8) are dominated by changes in global-mean potential temperature (Goodwin et al. 2011): $\mathrm{C}^{\text {sat }}\left(\theta, \mathrm{S}, \mathrm{A}^{\text {pre }}\right)$ is generally reduced with greater residual 
Table 2 Changes in carbon reservoirs in response to perturbations in Southern Ocean winds

\begin{tabular}{|c|c|c|c|c|}
\hline Expt & Inc & Dec & $\begin{array}{l}\text { North- } \\
\text { shifted }\end{array}$ & $\begin{array}{l}\text { South- } \\
\text { shifted }\end{array}$ \\
\hline$\Delta \mathrm{pCO}_{2}(\mu$ atm $)$ & 15.6 & -16.3 & 7.7 & -8.6 \\
\hline$\Delta \mathrm{C}^{\text {net }}(\mathrm{PgC})$ & -33.0 & 34.7 & -16.1 & 18.4 \\
\hline$\Delta \mathrm{C}^{\mathrm{sat}}\left(\mathrm{pCO}_{2}\right)(\mathrm{PgC})$ & 127.4 & -144.2 & 63.8 & -74.8 \\
\hline $\begin{array}{l}\Delta \mathrm{C}^{\text {sat }}\left(\theta, \mathrm{S}, \mathrm{A}^{\text {pre }}\right) \\
(\operatorname{PgC})\end{array}$ & -30.1 & 53.9 & -35.1 & 128.4 \\
\hline$\Delta \mathrm{C}^{\text {sat }}(\theta)(\mathrm{PgC})$ & -38.4 & 58.1 & -33.0 & 108.6 \\
\hline$\Delta \mathrm{C}^{\text {sat }}(\mathrm{S})(\mathrm{PgC})$ & 0.0 & -0.1 & -0.3 & 0.2 \\
\hline$\Delta \mathrm{C}^{\text {sat }}\left(\mathrm{A}^{\text {pre }}\right)(\mathrm{PgC})$ & 8.3 & -4.2 & -1.8 & 19.5 \\
\hline$\Delta \mathrm{C}^{\text {soft }}(\mathrm{PgC})$ & -95.5 & 92.2 & -9.7 & -80.5 \\
\hline$\Delta \mathrm{C}^{c a r b}(\mathrm{PgC})$ & -11.4 & 9.8 & -0.3 & -16.3 \\
\hline$\Delta \mathrm{C}^{d i s}(\mathrm{PgC})$ & -23.8 & 22.9 & -34.9 & 61.0 \\
\hline$\Delta \mathrm{C}^{\text {vflux }}(\mathrm{PgC})$ & 0.0 & 0.0 & 0.5 & 0.5 \\
\hline Residual error $(\mathrm{PgC})$ & -0.4 & -0.1 & -0.6 & -0.8 \\
\hline
\end{tabular}

$\Delta \mathrm{pCO}_{2}$ is the atmospheric $\mathrm{pCO}_{2}$ anomaly, $\Delta \mathrm{C}^{\text {net }}$ is the total change in the ocean carbon inventory (negative indicates ocean outgassing) followed by anomalies of the components of the carbon cycle (1), including a breakdown of the constituents of $\Delta \mathrm{C}^{\text {sat }} . \Delta \mathrm{C}^{\text {vflux }}$ is the net virtual flux of $\mathrm{CO}_{2}$ (negative indicates oceanic outgassing) that accounts for evaporation and precipitation at the sea surface. Finally, the residual error is the sum of all the ocean components (subtracting $\Delta \mathrm{C}^{\text {net }}$ and $\Delta \mathrm{C}^{v f l u x}$ ) and has a mean value of only $-0.5 \mathrm{PgC}$

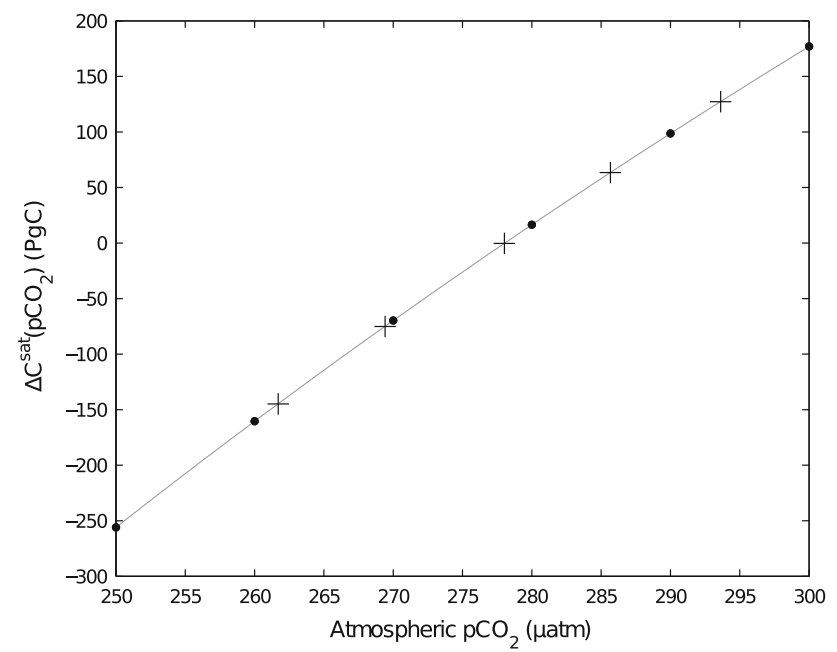

Fig. 7 Globally integrated anomaly (in $\mathrm{PgC}$ ) of the $\mathrm{C}^{\text {sat }}$ reservoir that depends only on the change in atmospheric $\mathrm{CO}_{2}$ compared to the control. The steady state inventories for the model perturbations for decreased, south-shifted, control, north-shifted and increased westerlies respectively with increasing $\mathrm{pCO}_{2}$ values (crosses, left to right. See also Table 2), together with values of $\Delta \mathrm{C}^{\text {sat }}\left(\mathrm{pCO}_{2}\right)$ calculated at arbitrary values of $\mathrm{pCO}_{2}$ (circles)

circulation and warmer pycnocline, while enhanced $\mathrm{C}^{\text {sat }}\left(\theta, \mathrm{S}, \mathrm{A}^{\text {pre }}\right)$ results from decreased residual overturning and a cooler pycnocline (Table 2$)$. The $\mathrm{C}^{\text {sat }}\left(\theta, \mathrm{S}, \mathrm{A}^{\text {pre }}\right)$ anomalies in the upper ocean oppose those in the deep ocean when the wind-stress magnitude is perturbed, but generally reinforce each other when the latitude of maximum wind-stress changes.

Preformed alkalinity also has a modest effect on $\Delta \mathrm{C}^{\text {sat }}\left(\theta, \mathrm{S}, \mathrm{A}^{\text {pre }}\right)$, concentration, with opposing contributions from the upper mode waters and deep ocean (Table 2). Increased alkalinity shifts the buffered carbon equilibrium away from dissolved $\mathrm{CO}_{2}$ and towards carbonate and bicarbonate ions, allowing greater oceanic uptake of $\mathrm{CO}_{2}$ from the atmosphere and increasing the size of the $\mathrm{C}^{\text {sat }}$ reservoir (e.g. Omta et al. 2011).

In summary, increased Southern Ocean residual circulation generally decreases the $\mathrm{C}^{\text {sat }}$ reservoir and acts to increase atmospheric $\mathrm{CO}_{2}$, while decreased residual circulation has the opposite effect (Table 2).

\subsubsection{Anomalies of the soft tissue and carbonate pools, $\Delta \mathrm{C}^{\text {soft }}$ and $\Delta \mathrm{C}^{\text {carb }}$}

A more vigorous residual circulation leads to increased upwelling of nutrient-rich waters and slightly increased production south of $40^{\circ} \mathrm{S}$. However, these upwelled nutrients are unable to be fully utilized due to reduced residence time in the surface layer and a combination of light and iron limitation in the Southern Ocean (e.g. Dutkiewicz et al. 2006), and so a greater proportion of upwelled nutrients are eventually subducted into the ocean interior. This enhanced subduction of nutrients leads to a widespread decrease in carbon stored in both the $\mathrm{C}^{\text {soft }}$ and $\mathrm{C}^{\text {carb }}$ reservoirs (Figs. 9a, 10a; Table 2). Conversely, reduced residual overturning under weaker westerlies reduces the surface nutrient supply, leading to slightly decreased biological production at high latitudes. However, at the same time, there is reduced subduction of preformed nutrients leading to increased overall nutrient utilization and increased carbon stored in the $\mathrm{C}^{\text {soft }}$ and $\mathrm{C}^{\text {carb }}$ reservoirs (Figs. 9b, 10b).

Ito and Follows (2005) quantified this connection by evaluating $P^{*}$, the fraction of biologically regenerated phosphate to the total phosphate concentration:

$P^{*}=\frac{P^{r e g}}{\left[P O_{4}^{3^{-}}\right]}$,

where $P^{r e g}=R_{P: O_{2}} A O U$. If export production ceased, then all the surface nutrients would be returned to the ocean interior by subduction and water-mass formation, $P^{*}$ would be zero and the ocean carbon inventory would be low. However, if surface nutrients were completely depleted then all the nutrients would be returned to the ocean interior by biological export and $P^{*}$ would approach unity. For a fixed global phosphate reservoir and fixed Redfield ratios, global mean $P^{*}$ is proportional to the size of the $\mathrm{C}^{\text {soft }}$ 

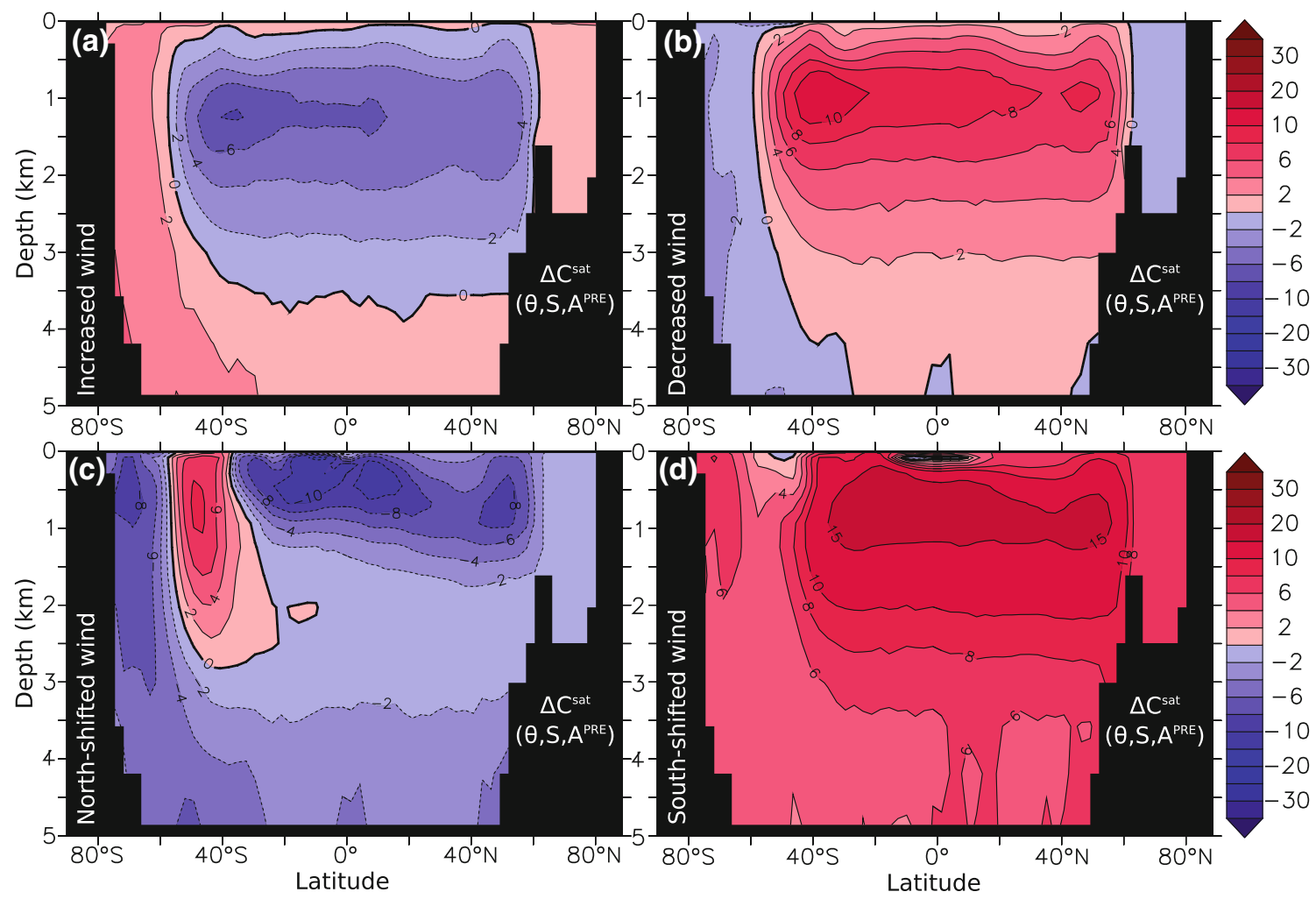

Fig. 8 Zonally-averaged anomaly $\left(\mathrm{mmol} \mathrm{C} \mathrm{m}^{-3}\right)$ of the $\mathrm{C}^{\text {sat }}$ reservoir that depends on changes in potential temperature, salinity and preformed alkalinity at the atmospheric $\mathrm{pCO}_{2}$ of control run $\left(\Delta \mathbf{C}^{\text {sat }}\left(\theta, \mathrm{S}, \mathrm{A}^{\text {pre }}\right)\right)$ for a increased, $\mathbf{b}$ decreased, $\mathbf{c}$ northward-shifted

and $\mathbf{d}$ southward-shifted westerly winds compared to the control (see also Table 2)

reservoir. Efficiency of the soft-tissue production as measured by $P^{*}$ is $35.7 \%$ in the control run, which decreases to $33.0 \%$ with stronger Southern Hemisphere winds and increases to $38.3 \%$ with weaker winds.

For meridional shifts in the latitude of the westerly winds, there are carbon and nutrient changes in both the upper ocean and abyss. In the upper ocean, a northward shift deepens the pycnocline and reduces the concentration of regenerated carbon and nutrients, while in the deep ocean, isolation of abyssal isopycnals causes accumulation of regenerated carbon and nutrients. The net effect is little overall change in the efficiency of soft tissue cycling with $P^{*}$ remaining close to the control at $34.4 \%$. Conversely, a southward shift shoals the pycnocline and increases regenerated carbon concentration (Figs. 9c, d, 10c, d), while in the deep ocean significant shoaling and outcropping of the densest isopycnals returns regenerated carbon and nutrients back to the surface, decreasing $P^{*}$ to $33.4 \%$.

Globally integrated $\Delta C^{\text {soft }}$ (Table 2) is generally much larger than the cumulative carbon exchanged with the atmosphere, while those for $\Delta \mathrm{C}^{\mathrm{carb}}$ is generally smaller. The biogenic reservoir response is more complex than the response of the saturated reservoir because of opposing

contributions linked to pycnocline changes and the outcrop of dense isopycnals (Figs. 9, 10).

\subsubsection{Changes in the disequilibrium carbon reservoir, $\Delta \mathrm{C}^{\text {dis }}$}

The size of the disequilibrium reservoir, $\mathrm{C}^{\text {dis }}$, reflects the mismatch between the DIC concentration and the $\mathrm{C}^{\text {sat }}$ and $\mathrm{C}^{\text {soft }}$ reservoirs, which exists because the timescale for airsea equilibration of $\mathrm{CO}_{2}$ is similar to the residence time of waters in the surface layer. In the North Atlantic deep water formation regions, cooling of surface waters and deep convection results in a negative $\mathrm{C}^{\text {dis }}$ signal that spreads over much of the ocean interior (Figs. $6 \mathrm{~g}, \mathrm{~h}, 11$ ). On the other hand, in the Southern Ocean, upwelling of regenerated carbon and nutrients, warming of northward flowing Antarctic surface waters and limited residence time in the surface layer for $\mathrm{CO}_{2}$ outgassing results in a more positive $\mathrm{C}^{\text {dis }}$ signal in intermediate and bottom waters.

When the strength of the westerly winds is increased, the stronger residual circulation and greater northward Ekman transport leads to increased surface warming, which coupled with reduced residence time in the surface layer 

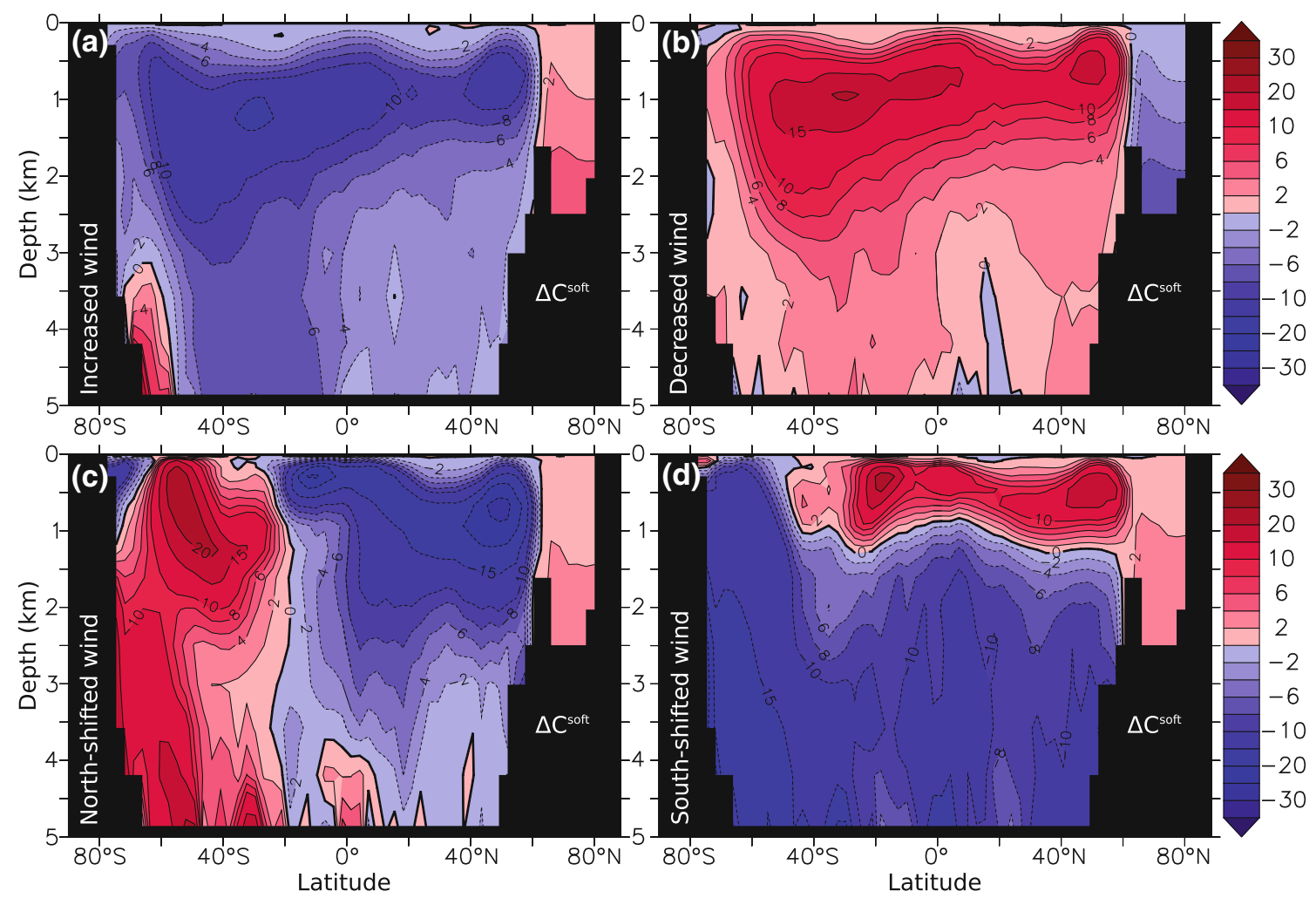

Fig. 9 Zonally-averaged anomaly ( $\mathrm{mmol} \mathrm{C} \mathrm{m}^{-3}$ ) of the $\mathrm{C}^{\text {soft }}$ reservoir for a increased, b decreased, $\mathbf{c}$ northward-shifted and $\mathbf{d}$ southward-shifted westerly winds compared to the control (see also Table 2)
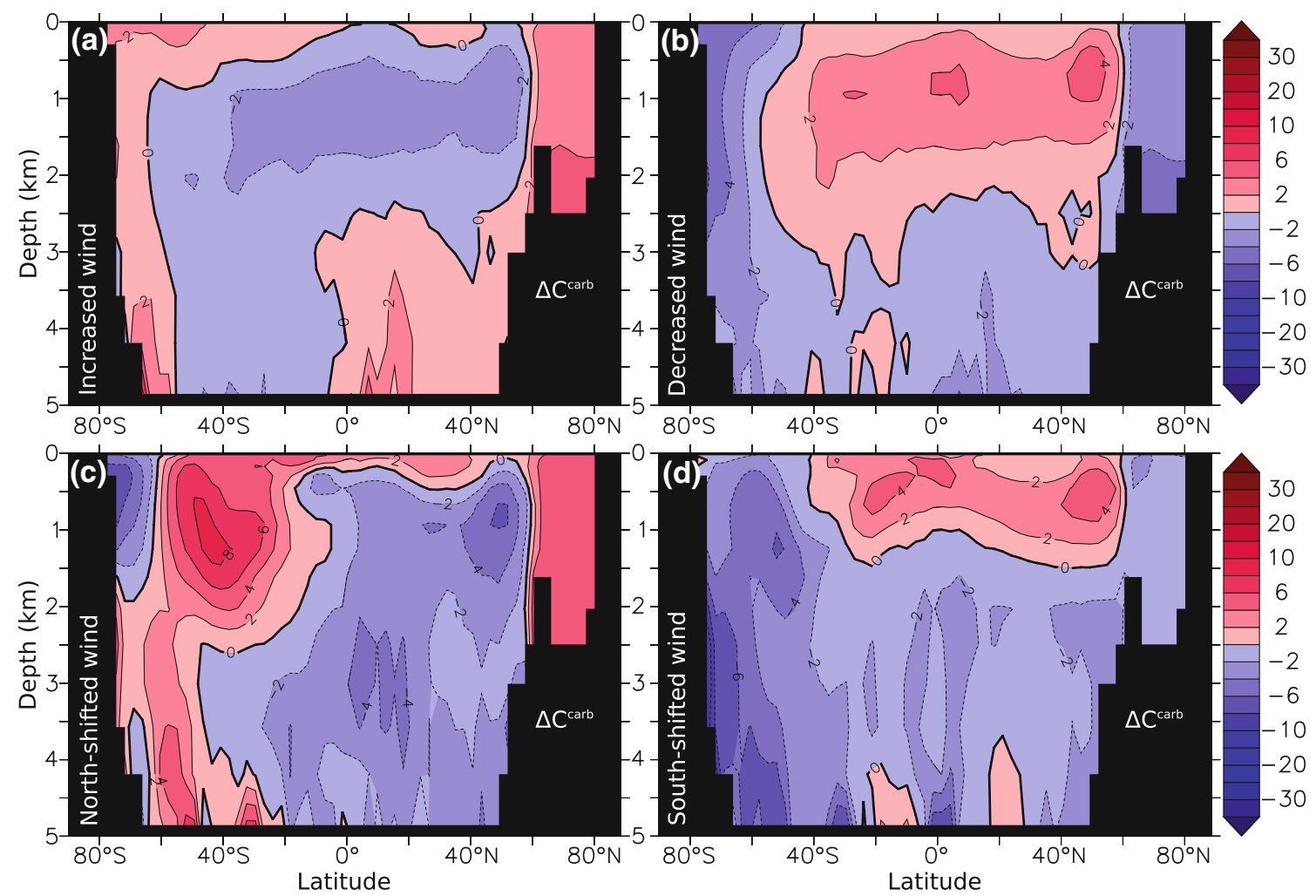

Fig. 10 Zonally-averaged anomaly $\left(\mathrm{mmol} \mathrm{C} \mathrm{m}{ }^{-3}\right)$ of the $\mathrm{C}^{\text {carb }}$ reservoir for a increased, b decreased, $\mathbf{c}$ northward-shifted and $\mathbf{d}$ southwardshifted westerly winds compared to the control (see also Table 2) 
inhibits complete outgassing of $\mathrm{CO}_{2}$ resulting in positive upper ocean $\Delta C^{\text {dis }}$ (Fig. 12a). The greater concentration of preformed nutrients in the ocean interior (as suggested by decreased $P^{*}$ ) leads to a reduced concentration of regenerated carbon being upwelled and therefore subduction of a more negative $\mathrm{C}^{\text {dis }}$ in bottom waters, despite reduced residence time at the surface. In addition, greater upwelling of Circumpolar Deep Water, derived from North Atlantic Deep Waters carrying a strong negative $\mathrm{C}^{\text {dis }}$ signal, reinforce the negative abyssal $\Delta \mathrm{C}^{\text {dis }}$. Conversely for weaker westerly winds, reduced residual circulation leads to weaker warming in water masses advected northward towards the intermediate and mode water subduction regions, and coupled with longer surface layer residence times, oceanic oversaturation is reduced and a more negative $\mathrm{C}^{\text {dis }}$ signature is subducted into the upper ocean. Furthermore, increased biological efficiency (higher $P^{*}$ ) leads to more regenerated carbon being upwelled to the surface waters of the Southern Ocean, which enhances the positive $\mathrm{C}^{\text {dis }}$ signal in the bottom waters and leads to positive $\Delta \mathrm{C}^{\text {dis }}$. Again, this positive signal is reinforced by reduced supply of deep waters of northern origin with a negative $\mathrm{C}^{\text {dis }}$ signal (Figs. 11b, 12b).

With a northward shift in the westerlies, the increased residual circulation and greater surface warming, coupled with a northward shift of the subduction region results in an increase in $\mathrm{C}^{d i s}$ around $20^{\circ} \mathrm{S}$ in the upper $500 \mathrm{~m}$ (Figs. 11c, $12 \mathrm{c})$. Reduced exposure of upwelled regenerated carbon at the surface due to slight decline in $P^{*}$ and isolation of abyssal isopycnals leads to bottom waters being formed with a more negative $\mathrm{C}^{\text {dis }}$ signature.

With a southward shift in the westerlies, reduced residual circulation with weaker northward warming and increased residence time at the surface results in a less positive $\mathrm{C}^{\text {dis }}$ signal and a negative $\Delta \mathrm{C}^{\text {dis }}$ anomaly subducted in the mode waters of the upper ocean (Figs. 11c, 12c). However, in the deep Southern Ocean a greater concentration of $\mathrm{C}^{\text {soft }}$ is returned to the surface as a result of outcropping of dense bottom waters, creating a more positive $C^{d i s}$ signal in the surface layer, which is then transferred back into the deep ocean in regions of bottom water formation in the Southern Ocean, resulting in a relatively large increase in $\Delta \mathrm{C}^{\text {dis }}$ in the abyss.

When these anomalies are integrated (Table 2), the deep ocean changes dominate the net anomaly in the $\mathrm{C}^{\text {dis }}$ reservoir, particularly for southward shifted winds.

3.5 Summary of the relationship between carbon components and ocean physics

The close relationship between changes in atmospheric $\mathrm{CO}_{2}$ and the Southern Ocean residual circulation in our model reveals a strong control by ocean physics (Fig. 2b). A mechanistic view of the changes in the carbon components is obtained by applying the carbon framework to all 27 members of the model suite. Changes in residual circulation explain $83 \%$ of the variance in the total saturated pool of DIC, including changes resulting from atmospheric $\mathrm{CO}_{2}$ and potential temperature, salinity and alkalinity anomalies. When considered separately, the relationship between the residual circulation and $\Delta \mathrm{C}^{\text {sat }}\left(\theta, \mathrm{S}, \mathrm{A}^{\text {pre }}\right)$ is fairly close for all experiments, controlled by ventilated changes in pycnocline depth. For southward-shifted winds of $10^{\circ}$, there are larger reductions in atmospheric $\mathrm{CO}_{2}$ due to $\Delta \mathrm{C}^{\text {sat }}\left(\theta, \mathrm{S}, \mathrm{A}^{\text {pre }}\right)$ than would be expected from the relatively modest overturning rates, suggesting that changes in $\mathrm{C}^{\text {sat }}$ due to the cooling of deep waters becomes more important (Fig. 8d).

The negative relationship between the biogenic store of carbon and Southern Ocean overturning is also relatively good: strong residual circulation decreasing biological efficiency by subduction of unutilized nutrients from the surface and promoting $\mathrm{CO}_{2}$ outgassing, whereas weak residual overturning increases efficiency through greater surface nutrient usage. This negative relationship was previously reported by Parekh et al. (2006), addressing how the soft-tissue carbon pump affects atmospheric $\mathrm{CO}_{2}$.

There is a large contribution from the abyssal ocean when winds are shifted to the south leading to much greater outgassing as $\mathrm{C}^{\text {soft }}$ in bottom waters is upwelled (Fig. 9d). Finally the disequilibrium reservoir, $\mathrm{C}^{d i s}$, is affected by interactions with the $\mathrm{C}^{\text {sat }}$ and $\mathrm{C}^{\text {soft }}$ reservoirs, particularly related to the extent regenerated carbon is upwelled and the residence time in the surface, allowing outgassing to occur prior to subduction.

\section{Discussion}

The effect of the Southern Ocean winds on the ocean cycling of carbon and atmospheric $\mathrm{CO}_{2}$ is investigated using a series of idealized experiments with a global coarse-resolution ocean circulation and biogeochemistry model. There is a striking positive correlation between the strength of the residual circulation and atmospheric $\mathrm{CO}_{2}$ with a sensitivity of roughly $1.5 \mu \mathrm{atm} \mathrm{Sv}{ }^{-1}$ based on our suite of 27 model experiments. This positive correlation is in accord with previous, although more limited, modeling studies (e.g. Menviel et al. 2008; Tschumi et al. 2008; Parekh et al. 2006; d'Orgeville et al. 2010).

There are two main mechanisms at work during these wind-stress perturbation experiments: firstly, there are changes in the Southern Ocean upwelling of deep waters and subduction of intermediate and mode waters in the 

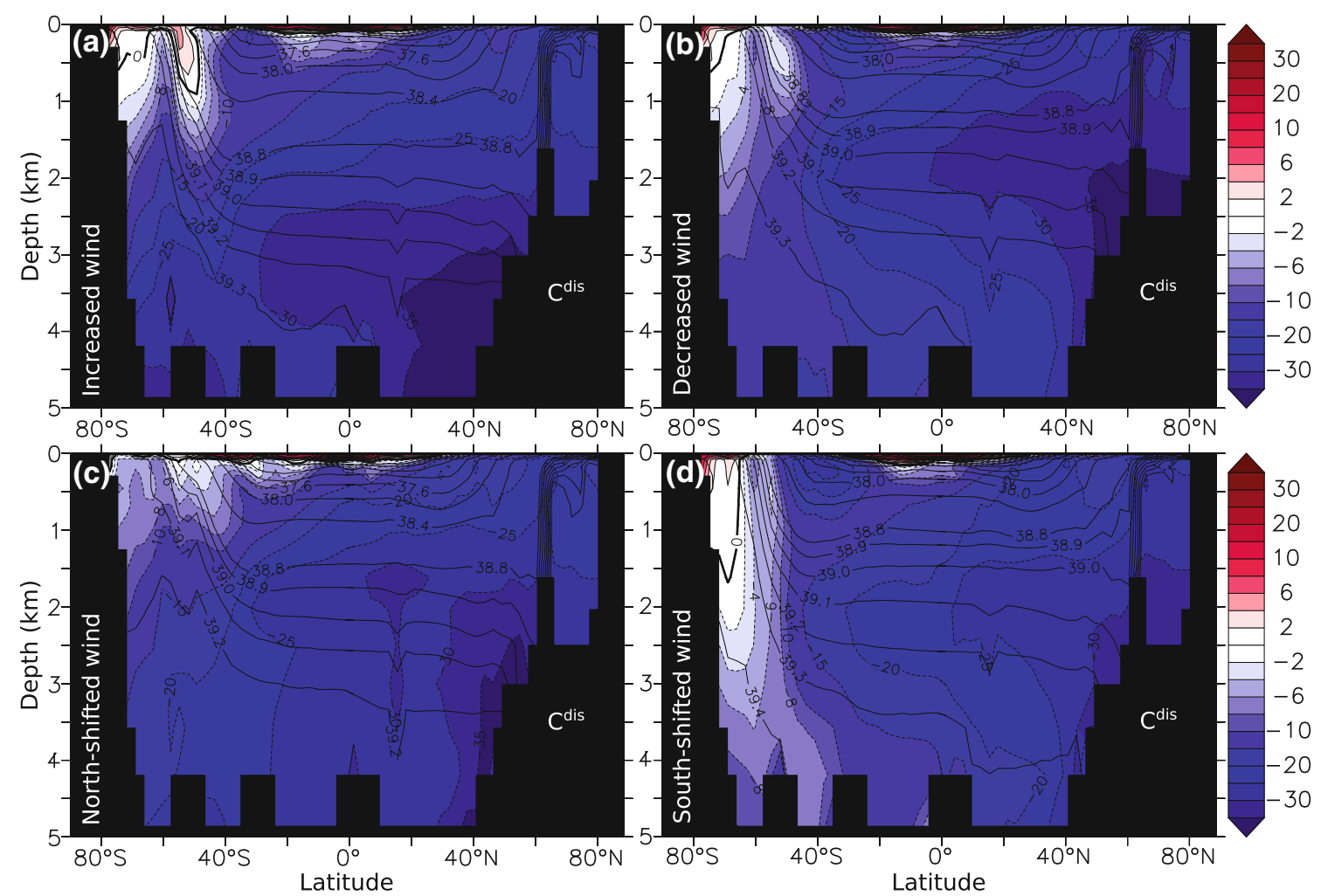

Fig. 11 Zonally-averaged Atlantic Ocean section $\left(\mathrm{mmol} \mathrm{C} \mathrm{m}{ }^{-3}\right)$ of the $\mathrm{C}^{\text {dis }}$ reservoir with $\sigma_{2.5}$ density contours overlaid for a increased, b decreased, c northward-shifted and $\mathbf{d}$ southward-shifted westerly winds
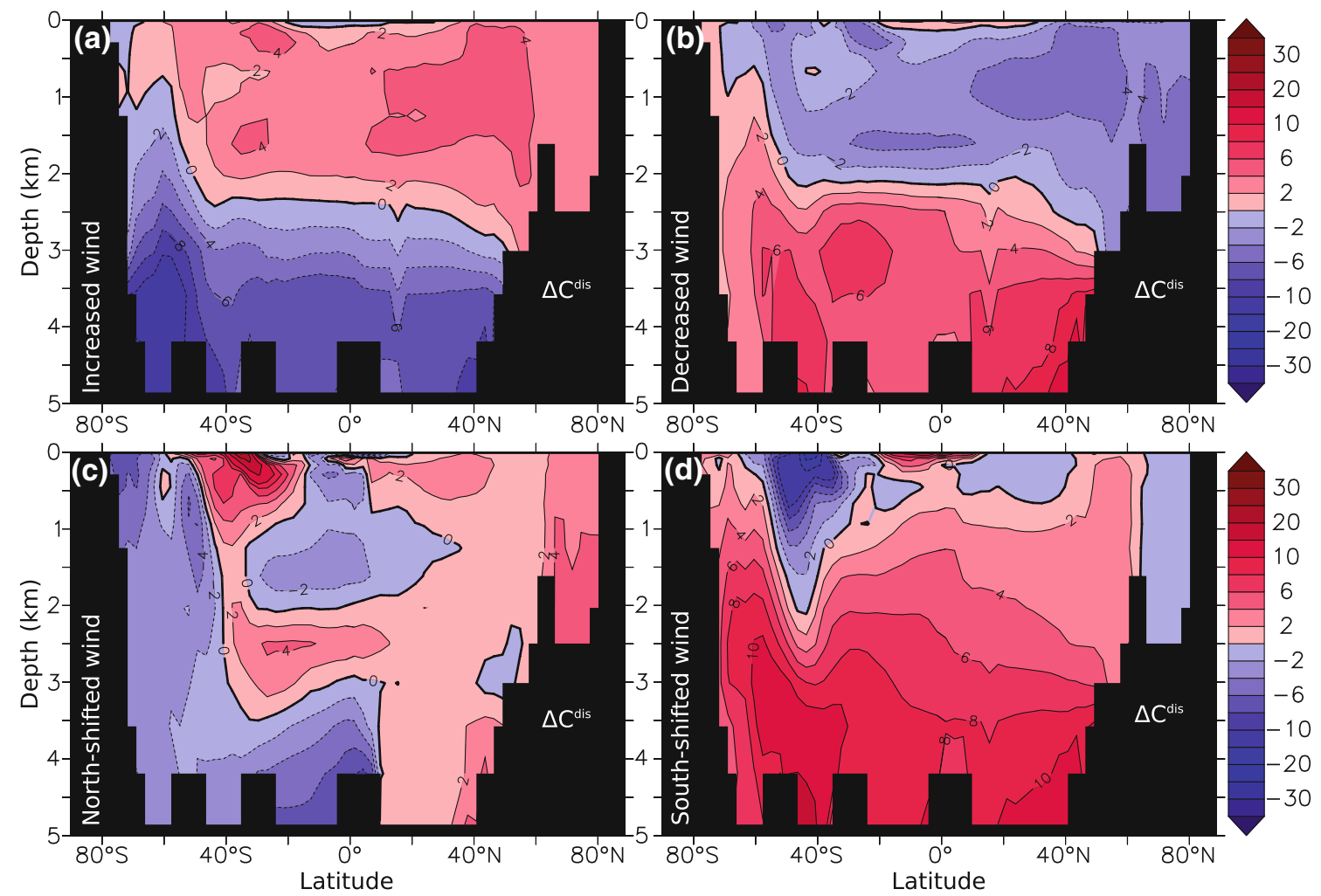

Fig. 12 Zonally-averaged Atlantic Ocean anomaly $\left(\mathrm{mmol} \mathrm{C} \mathrm{m}^{-3}\right)$ of the $\mathrm{C}^{\text {dis }}$ reservoir for a increased, b decreased, c northward-shifted and d southward-shifted westerly winds 
upper ocean associated with the residual circulation and, secondly, there is a reorganization in the extent of dense bottom waters in the Southern Hemisphere (Fig. 13). The detailed carbon response can be understood in terms of the separate reservoirs, involving saturated, biogenic and disequilibrium anomalies. All of these pools are important in accounting for the net change in atmospheric $\mathrm{CO}_{2}$ reaching $\pm 20 \mu \mathrm{atm}$ and they often have partly compensating responses when integrated over the global ocean (Table 2).

An increase in the residual circulation in our model leads to direct enhancement in upwelling and ventilation of the upper ocean resulting in a reduction in the saturated component, $\mathrm{C}^{\text {sat }}$, due to warmer upper waters, and the disequilibrium component, $\mathrm{C}^{\text {dis }}$, due to reduced residence time of waters at the sea surface. A stronger residual circulation also enhances the delivery of nutrients to the

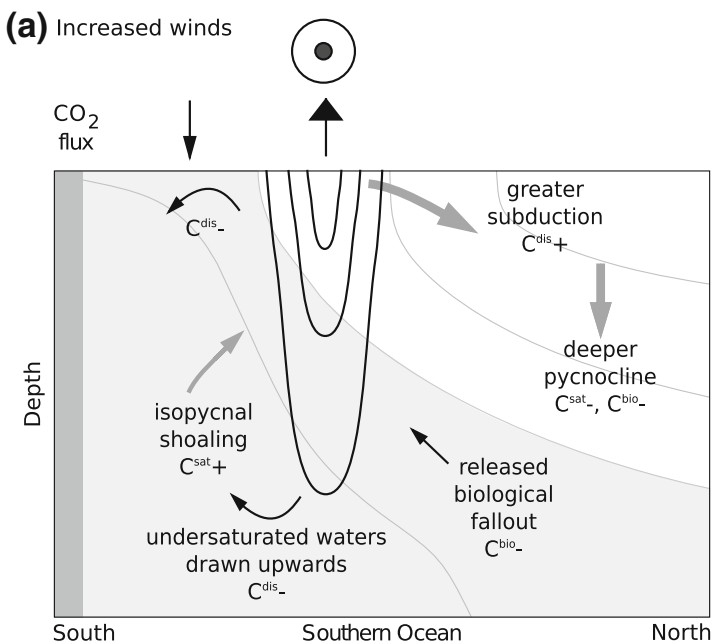

(c) Northward shifted winds

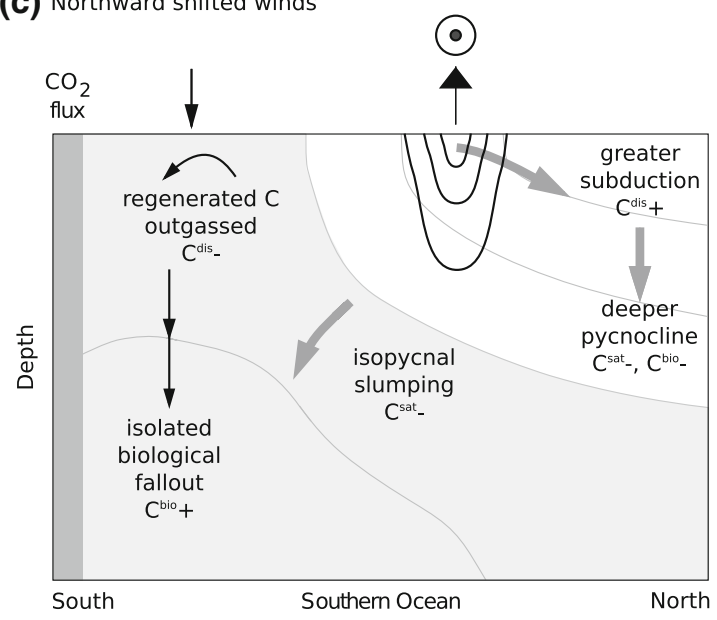

Fig. 13 A schematic depicting the main causes of atmospheric $\mathrm{CO}_{2}$ anomalies when Southern Hemisphere winds are a increased, b decreased, c shifted north or $\mathbf{d}$ shifted south. The rate of the residual circulation controls the formation and ventilation of intermediate and mode waters that influence the depth of the low latitude pycnocline, the upper ocean concentration of $\mathrm{C}^{\text {sat }}$, the biogenic pool surface layer and the export of unutilized, preformed nutrients in intermediate and mode waters, which reduces the $\mathrm{C}^{\text {soft }}$ and $\mathrm{C}^{\text {carb }}$ reservoirs, reflecting decreased biological efficiency. A similar connection between the residual circulation and $C^{\text {soft }}$ is obtained by Parekh et al. (2006).

In addition to the upper ocean changes, the position of the peak westerly winds alters the abyssal density structure in the modeled Southern Ocean. When the westerlies are shifted northward, isopycnal slumping and isolation occurs, which increases the deep ocean store of $\mathrm{C}^{\text {soft }}$ and $\mathrm{C}^{\text {carb }}$, and decreases the $\mathrm{C}^{\text {sat }}$ and $\mathrm{C}^{\text {dis }}$ reservoirs. On the other hand, when the westerlies shift southward, isopycnal shoaling and deep ocean ventilation occurs and the opposite response occurs. This deep response is broadly similar to the hypothesis of Toggweiler et al (2006), where a northward shift in the westerlies is viewed as allowing

(b) Decreased winds

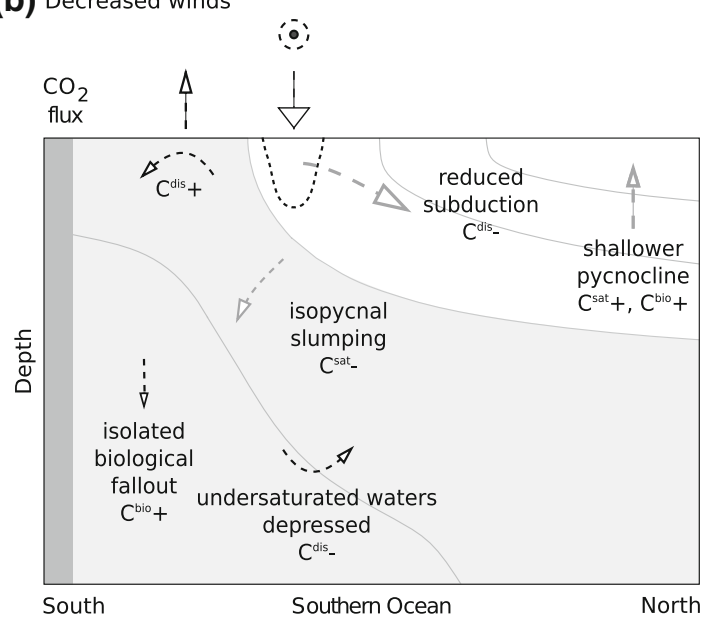

(d) Southward shifted winds

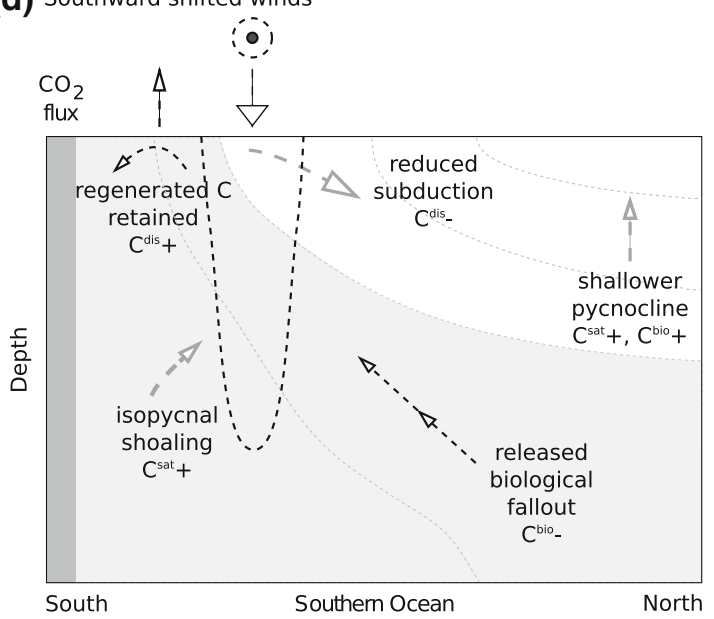

$\mathrm{C}^{\text {bio }}=\mathrm{C}^{\text {soft }}+\mathrm{C}^{\text {carb }}$ and the disequilibrium concentration, $\mathrm{C}^{\text {dis }}$. On the other hand, the vertical extent of the overturning circulation, linked to the proximity of the westerlies and the unblocked latitudes of Drake Passage influences the outcropping of dense isopycnals, which primarily affects $C^{b i o}$ and $C^{d i s}$ 
regenerated DIC to accumulate in the abyssal Southern Ocean, while a southward shift transfers regenerated DIC into the atmosphere. However, in our suite of model experiments, the carbon changes in the upper ocean turn out to be more important than the opposing changes in the abyssal ocean.

Based on our model sensitivity experiments, the Southern Hemisphere westerly winds exert an influence on the ocean's pycnocline and the residual circulation, varying with the globally integrated mechanical energy input by the work done by the winds on the geostrophic circulation (Table 1, Lauderdale et al. 2012). In these experiments, the changes in ventilation of intermediate and mode waters generates persistent anomalies in the ocean carbon inventory and atmospheric $\mathrm{CO}_{2}$. In turn, these atmospheric $\mathrm{CO}_{2}$ changes can only be understood by considering all the carbon components, rather than individual components in isolation.

Speculating about the wider implications of our model sensitivity studies, our view of the influence of residual circulation and upper ocean ventilation on atmospheric $\mathrm{CO}_{2}$ is partly in accord with inferences from the past: during glacial periods there is reduced intermediate water production from the Southern Ocean and low concentrations of atmospheric $\mathrm{CO}_{2}$ and, conversely, during interglacial periods there is increased intermediate and mode water volume and higher atmospheric $\mathrm{CO}_{2}$ (Pahnke and Zahn 2005; Pahnke et al. 2008). However, based on reconstructions of limited latitudinal shifts in the Southern Hemisphere westerlies during the last glacial (e.g. Shulmeister et al. 2004; Rojas et al. 2009; Chavaillaz et al. 2012), our model experiments with $\pm 3^{\circ}$ shifts in the latitude of the maximum westerly wind and modest buoyancy forcing changes are unlikely to explain large variations of atmospheric $\mathrm{CO}_{2}$. This does not discount wind-induced changes playing a role as part of a combination of factors leading into or out of a glacial (e.g. Peacock et al. 2006; Kohfeld and Ridgwell 2009). Future changes in the strength of the Southern Ocean natural $\mathrm{CO}_{2}$ sink might depend on the eventual position and strength of the Southern Hemisphere westerlies, with a small increase in sink strength with a southward shift in our experiments masked by a potentially large decrease in sink strength associated with increased westerly winds.

There are two important caveats though in our model experiments. Firstly, the experiments utilize a coarse-resolution model and only include parameterization of mesoscale eddies so that our conclusions regarding the residual circulation and the sensitivity of atmospheric $\mathrm{pCO}_{2}$ might be affected (e.g. Hallberg and Gnanadesikan 2006; Böning et al. 2008; Viebahn and Eden 2010; Jones et al. 2011; Meredith et al. 2011; Shakespeare and Hogg 2012).

Secondly, the experiments only include limited changes in the buoyancy forcing associated with the wind perturbations and there is no climate feedback due to changing atmospheric $\mathrm{pCO}_{2}$. Toggweiler et al. (2006) argues that during glacial-interglacial transitions, the ventilation of the abyssal ocean was achieved by the formation and erosion of a low-salinity surface water layer around Antarctica. Our model experiments with "mixed" surface buoyancy boundary conditions only include limited salinity changes of $\mathrm{O}\left(0.1 \mathrm{~g} \mathrm{~kg}^{-1}\right)$, compared with the $\mathrm{O}\left(1 \mathrm{~g} \mathrm{~kg}^{-1}\right)$ changes invoked by Toggweiler et al. (2006). While our experiments do reveal some buoyancy-driven changes in abyssal circulation, we also find that there are compensating carbon changes: carbon component anomalies of saturation and disequilibrium associated with model circulation changes are largely compensated by opposing anomalies in the soft tissue reservoir. If climatic perturbations to the Southern Hemisphere westerly winds are to induce greater changes in atmospheric $\mathrm{CO}_{2}$, then larger accompanying changes in surface heat and freshwater fluxes have to be invoked than applied here.

In summary, moderate $( \pm 20 \mu \mathrm{atm})$ changes in atmospheric $\mathrm{CO}_{2}$ are positively correlated with wind-induced changes in the Southern Ocean residual circulation in our suite of idealized model sensitivity experiments with limited changes in buoyancy forcing and parameterized mesoscale eddy activity. These changes in atmospheric $\mathrm{CO}_{2}$ are dominated by the contribution of the upwelling of carbon-rich deep waters and the ventilation of upper ocean mode waters, rather than changes in the abyssal store of carbon.

Acknowledgments JML was supported by a UK NERC PhD Studentship (NER/S/A/2006/14210) and by UK NERC grant NE/ G018782/1. Thanks to Chris Hughes and Chris Wilson for useful discussions concerning the virtual salt flux and to J. R. Toggweiler and two anonymous reviewers for comments that improved this work.

\section{Appendix: Carbon partitioning framework}

The in situ concentration of dissolved inorganic carbon $\left(C^{D I C}\right)$ is decomposed into four main pools (Brewer 1978; Chen and Millero 1979; Gruber et al. 1996; Ito and Follows 2005; Williams and Follows 2011),

$C^{D I C}=C^{s a t}+C^{s o f t}+C^{c a r b}+C^{d i s}$.

$\mathrm{C}^{\text {sat }}$ is the saturated DIC concentration of a water-mass at the surface in equilibrium with the overlying atmosphere, which is a function of atmospheric carbon dioxide partial pressure $\left(\mathrm{pCO}_{2}\right)$, potential temperature $(\theta)$, salinity $(\mathrm{S})$ and preformed alkalinity $\left(\mathrm{A}^{\text {pre }}\right)$,

$C^{\text {sat }}=f\left(p \mathrm{CO}_{2} \theta, S, A^{p r e}\right)$.

A relationship for $\mathrm{A}^{\text {pre }}$ is obtained by multiple linear regression against sea surface salinity (S) and the 
conservative tracer PO (where $\mathrm{PO}=\mathrm{O}_{2}-\mathrm{R}_{\mathrm{P}: \mathrm{O}_{2} \mathrm{PO}_{4} \text { is }}$ the oxygen distribution with alterations due to respiration and remineralization of biogenic phosphate removed, Broecker 1974),

$A^{\text {pre }}=0.11+(0.06 \times S)+(0.10 \times P O)$.

For the majority of the surface ocean, alkalinity is dominated by salinity changes, however including PO is important where high nutrient, relatively high alkalinity deep waters are upwelled in the Southern Ocean (Gruber et al. 1996).

Anomalies in $\mathrm{C}^{\text {sat }}$ can be further separated to reveal the change in concentration due to each contributing factor (Goodwin and Lenton 2009),

$$
\begin{aligned}
\Delta C^{s a t}= & \left.\Delta p C O_{2} \frac{\partial C^{s a t}}{\partial p C O_{2}}\right|_{\theta, S, A^{p r e}}+\left.\Delta \theta \frac{\partial C^{s a t}}{\partial \theta}\right|_{p C O_{2}, S, A^{p r e}} \\
& +\left.\Delta S \frac{\partial C^{s a t}}{\partial S}\right|_{p C O_{2}, \theta, A^{p r e}}+\left.\Delta A^{p r e} \frac{\partial C^{s a t}}{\partial A^{p r e}}\right|_{p C O_{2}, \theta, S} .
\end{aligned}
$$

This separation assumes a linearization of the buffering capacity of the ocean carbonate system (for example, see Fig. 13.3 in Williams and Follows 2011), however over the range of anomalies generated here, (A.4) is an acceptable simplification. We consider the effects of altered atmospheric $\mathrm{CO}_{2}$ partial pressure $\left(\Delta \mathrm{C}^{\text {sat }}\left(\mathrm{pCO}_{2}\right)\right)$ and anomalies caused by ocean ventilation changes $\left(\Delta \mathrm{C}^{\text {sat }}\left(\theta, \mathrm{S}, \mathrm{A}^{\text {pre }}\right)\right)$ individually.

Biological production and remineralization of particulate organic carbon, $\mathrm{C}^{\text {soft }}$,

$C^{\text {soft }}=-R_{\mathrm{C}_{2} \mathrm{O}_{2}} \mathrm{AOU}$,

is calculated using apparent oxygen utilization (AOU, Ito et al. 2004a; Ito and Follows 2005),

$A O U=O_{2}^{s a t}(\theta, S)-O_{2}$.

Similarly, biological production and remineralization of sinking inorganic particulate carbon, $\mathrm{C}^{c a r b}$, is quantified through changes in regenerated alkalinity (the difference between in situ alkalinity, $\mathrm{A}^{T}$, and $\mathrm{A}^{\text {pre }}$ ),

$A^{T}=A^{\text {pre }}+A^{\text {reg }}$,

with a smaller component related to consumption and remineralization of molecularly-charged nutrients,

$C^{c a r b}=\frac{1}{2}\left(A^{T}-A^{\text {pre }}-R_{N: O_{2}} A O U\right)$.

Biological processes captured by PO, $\mathrm{C}^{\text {soft }}$ and $\mathrm{C}^{\text {carb }}$ are related by fixed stoichiometric ratios $\left(R_{[C: N: P: O]}\right)$ as prescribed in the biogeochemistry model.

Lastly, the disequilibrium reservoir, $\mathrm{C}^{\text {dis }}$, is the DIC concentration not accounted for by the components of (1). $\mathrm{C}^{\text {dis }}$ mainly represents the difference between $\mathrm{C}^{\text {sat }}$ and $\mathrm{C}^{D I C}$ when a water-mass was last in contact with the atmosphere. This disequilibrium occurs due to the timescale for complete $\mathrm{CO}_{2}$ exchange with the atmosphere, which is typically one year, being of the same order as the residence time of a water parcel at the sea surface (Ito et al. 2004b). Therefore deviations from the target $\mathrm{C}^{\text {sat }}$ concentration occur if subduction occurs before complete atmosphereocean $\mathrm{CO}_{2}$ exchange. Also, changes in atmospheric $\mathrm{CO}_{2}$ affect the entire oceanic $\mathrm{C}^{\text {sat }}$ reservoir by definition, driving the in situ concentration further from equilibrium and causing $\mathrm{C}^{\text {dis }}$ to vary inversely in order to compensate and rebalance (1) (Goodwin and Lenton 2009), particularly in deep waters.

As the residual, $\mathrm{C}^{\text {dis }}$ also contains minor errors associated with the component decomposition, such as the assumption of surface saturated dissolved oxygen for AOU (e.g. Ito et al. 2004a) and linearization of (A.4).

\section{References}

Anderson LA, Sarmiento JL (1994) Redfield ratios of remineralization determined by nutrient data analysis. Global Biogeochem Cycles 8:65-80

Anderson RF, Ali S, Bradtmiller LI, Nielsen SHH, Fleisher MQ, Anderson BE, Burckle LH (2009) Wind-driven upwelling in the Southern Ocean and the deglacial rise in atmospheric $\mathrm{CO}_{2}$. Science 323:1443-1448. doi:10.1126/science.1167441

Archer D, Winguth A, Lea D, Mahowald N (2000) What caused the glacial/interglacial atmospheric $\mathrm{pCO}_{2}$ cycles? Rev Geophys 38:159-189

Böning CW, Dispert A, Visbeck M, Rintoul SR, Schwartzkopf FU (2008) The response of the Antarctic circmpolar current to recent climate change. Nat Geosci 1:864-869. doi:10.1038/ngeo362

Brewer P (1978) Direct observation of oceanic $\mathrm{CO}_{2}$ increase. Geophys Res Lett 5:997-1000

Broecker WS (1974) NO: a conservative water-mass tracer. Earth Planet Sci Lett 23:100-107

Chavaillaz Y, Codron F, Kageyama M (2012) Southern westerlies in lgm and future (rcp4.5) climates. Clim Past Discuss 8(4): 3693-3717. doi:10.5194/cpd-8-3693-2012

Chen G, Millero FJ (1979) Gradual increase of oceanic $\mathrm{CO}_{2}$. Nature 277:205-206

Chikamoto MO, Matsumoto K, Ridgwell A (2008) Response of deepsea caco3 sedimentation to atlantic meridional overturning circulation shutdown. J Geophys Res 113(G3):G03017. doi: 10.1029/2007JG000669

DeVries T, Primeau F (2009) Atmospheric $\mathrm{pCO}_{2}$ sensitivity to the solubility pump: Role of the low-latitude ocean. Global Biogeochem Cycles 23(4):GB4020. doi:10.1029/2009GB003537

Dong B, Valdes PJ (1998) Simulations of the last glacial maximum climates using a general circulation model: prescribed versus computed sea surface temperatures. Climate Dynam 14:571-591

d'Orgeville M, Sijp WP, England MH, Meissner KJ (2010) On the control of glacial-interglacial atmospheric $\mathrm{CO}_{2}$ variations by the Southern Hemisphere westerlies. Geophys Res Lett 37(21):L21703. doi: 10.1029/2010GL045261

Dutkiewicz S, Follows MJ, Parekh P (2005) Interactions of the iron and phosphorus cycles: a three dimensional model study. Global Biogeochem Cycles 19:GB1021. doi:10.1029/2004GB002342 
Dutkiewicz S, Follows MJ, Heimbach P, Marshall J (2006) Controls on ocean productvity and air-sea carbon flux: an adjoint model sensitivity study. Geophys Res Lett 33:L02603. doi:10.1029/ 2005GL024987

Follows MJ, Ito T, Marotzke J (2002) The wind-driven, subtropical gyres and the solubility pump of $\mathrm{CO}_{2}$. Global Biogeochem Cycles 16(4):1113. doi:10.1029/2001GB001786

Follows MJ, Ito T, Dutkiewicz S (2006) On the solution of the carbonate chemistry system in ocean biogeochemistry models. Ocean Model 12:290-301

Fyfe JC, Saenko OA, Zickfeld K, Eby M, Weaver AJ (2007) The role of poleward-intensifying winds on Southern Ocean warming. J Climate 20:5391-5400. doi:10.1175/2007JCLI1764.1

Gent PR, McWilliams J (1990) Isopycnal mixing in ocean circulation models. J Phys Oceanogr 20:150-155

Gill AE, Bryan K (1971) Effects of geometry on the circulation of a three-dimensional southern-hemisphere ocean model. Deep-Sea Res 18:685-721

Gloor M, Gruber N, Sarmiento JL, Sabine CL, Feely RA, Rödenbeck $\mathrm{C}$ (2003) A first estimate of present and preindustrial air-sea $\mathrm{CO}_{2}$ fluxes based on ocean interior carbon measurements and models. Geophys Res Lett 30. doi:10.1029/2002GL015594

Goodwin P, Lenton TM (2009) Quantifying the feedback between ocean heating and $\mathrm{CO}_{2}$ solubility as an equivalent carbon emission solubility as an equivalent carbon emission. Geophys Res Lett 36(15):L15609. doi:10.1029/2009GL039247

Goodwin P, Oliver KIC, Lenton TM (2011) Observational constraints on the causes of holocene $\mathrm{CO}_{2}$ change. Global Biogeochem Cycles 25(3):GB3011. doi:10.1029/2010GB003888

Gruber N, Sarmiento JL, Stocker TF (1996) An improved method for detecting anthropogenic $\mathrm{CO}_{2}$ in the oceans. Global Biogeochem Cycles 10(4):809-837

Hallberg R, Gnanadesikan A (2006) The role of eddies in determining the structure and response of the wind-driven southern hemisphere overturning: results from the modeling eddies in the Southern Ocean (MESO) project. J Phys Oceanogr 36:2232-2252

Huang RX, Wang W, Liu LL (2006) Decadal variability of windenergy input to the world ocean. Deep-Sea Res II 53(1-2):31-41. doi:10.1016/j.dsr2.2005.11.001

Ito T, Follows MJ (2005) Preformed phosphate, soft tissue pump and atmospheric $\mathrm{CO}_{2}$. J Mar Res 63:813-839

Ito T, Follows MJ, Boyle EA (2004a) Is AOU a good measure of respiration in the oceans? Geophys Res Lett 31:L17305. doi: 10.1029/2004GL020900

Ito T, Marshall J, Follows MJ (2004b) What controls the uptake of transient tracers in the Southern Ocean? Global Biogeochem Cycles 18:GB2021. doi:10.1029/2003GB002103

Jiang S, Stone PH, Malanotte-Rizzoli P (1999) An assessment of the geophysical fluid dynamics laboratory ocean model with coarse resolution: annual-mean climatology. J Geophys Res 104: 25623-25645

Jones DC, Ito T, Lovenduski NS (2011) The transient response of the southern ocean pycnocline to changing atmospheric winds. Geophys Res Lett 38(15):L15604. doi:10.1029/2011GL048145

Karsten RH, Marshall J (2002) Constructing the residual circulation of the ACC from observations. J Phys Oceanogr (32):3315-3327

Keeling RF, Visbeck M (2001) Antarctic stratification and glacial $\mathrm{pCO}_{2}$. Nature 412:605-606

Knox F, McElroy MB (1984) Changes in atmospheric $\mathrm{CO}_{2}$ : influence of the marine biota at high latitude. J Geophys Res 89(3): $4629-4637$

Kohfeld KE, Ridgwell A (2009) Glacial-interglacial variability in atmospheric $\mathrm{CO}_{2}$. In: Le Quéré C, Saltzman ES (eds) Surface ocean-lower atmosphere processes. Geophysical Monograph Series, vol 187. AGU, Washington, pp 251-286. doi:10.1029/2008 GM000845
Kwon EY, Sarmiento JL, Toggweiler JR, DeVries T (2011) The control of atmospheric $\mathrm{pCO}_{2}$ by ocean ventilation change: The effect of the oceanic storage of biogenic carbon. Global Biogeochem Cycles 25(3):GB3026. doi:10.1029/2011GB004059

Lauderdale JM (2010) On the role of the Southern Ocean in the global carbon cycle and atmospheric $\mathrm{CO}_{2}$ change. $\mathrm{PhD}$ thesis, School of Ocean and Earth Science. University of Southampton, Southampton

Lauderdale JM, Naveira Garabato AC, Oliver KIC, Thomas LN (2012) Climatic variations of the work done by the wind on the ocean's general circulation. J Geophys Res 117(C9):C09,017. doi:10.1029/2012JC008135

Le Quéré C, Rödenbeck C, Buitenhuis ET, Conway TJ, Langenfelds R, Gomez A, Labuschagne C, Ramonet M, Nakazawa T, Metzl N, Gillet N, Heimann M (2007) Saturation of the Southern Ocean $\mathrm{CO}_{2}$ sink due to recent climate change. Science 316: $1735-1738$

Le Quéré C, Rödenbeck C, Buitenhuis ET, Conway TJ, Langenfelds R, Gomez A, Labuschagne C, Ramonet M, Nakazawa T, Metzl N, Gillet N, Heimann M (2008) Response to comments on saturation of the Southern Ocean $\mathrm{CO}_{2}$ sink due to recent climate change. Science 319:570c. doi:10.1126/science.1147315

Lenton A, Matear RJ (2007) Role of the Southern annular mode (SAM) in Southern Ocean $\mathrm{CO}_{2}$ uptake. Global Biogeochem Cycles 21:GB2016. doi:10.1029/2006GB002714

Lovenduski NS, Gruber N (2005) Impact of the Southern annular mode on Southern Ocean circulation and biology. Geophys Res Lett 32:L11603. doi:10.1029/2005GL022727

Mahowald NM, Muhs DR, Levis S, Rasch PJ, Yoshioka M, Zender CS, Luo C (2006) Change in atmospheric mineral aerosols in response to climate: last glacial period, preindustrial, modern and doubled carbon dioxide climates. J Geophys Res 111:D10202. doi:10.1029/2005JD006653

Marinov I, Gnanadesikan A, Sarmiento JL, Toggweiler JR, Follows M, Mignone BK (2008) Impact of oceanic circulation on biological carbon storage in the ocean and atmospheric pco2. Global Biogeochem Cycles 22(3):GB3007. doi:10.1029/2007 GB002958

Marshall J, Radko T (2003) Residual mean solutions for the Antarctic circumpolar current and its associated overturning circulation. J Phys Oceanogr 33:2341-2354

Marshall J, Speer K (2012) Closure of the meridional overturning circulation through southern ocean upwelling. Nat Geosci 5(3):171-180. doi:10.1038/ngeo1391

Marshall J, Adcroft A, Hill C, Perelman L, Heisey C (1997) A finitevolume, incompressible Navier Stokes model for studies of the ocean on parallel computers. J Geophys Res 102(C3):5753-5766

McCulloch RD, Bentley MJ, Purves RS, Hulton NRJ, Sugden DE, Clapperton CM (2000) Climatic inferences from glacial and palaeoecological evidence at the last glacial termination, southern South America. J Quat Sci 15(4):409-417

McKinley GA, Follows MJ, Marshall J (2004) Mechanisms of air-sea $\mathrm{CO}_{2}$ flux variability in the equatorial Pacific and the North Atlantic. Global Biogeochem Cycles 18(2):GB2011. doi: 10.1029/2003GB002179

Menviel L, Timmerman A, Mouchet A, Timm O (2008) Climate and marine carbon response to changes in the strength of the Southern Hemispheric westerlies. Paleoceanography 33:PA4201. doi:10.1029/2008PA001604

Meredith MP, Naveira Garabato AC, Hogg AM, Farneti R (2011) Sensitivity of the overturning circulation in the southern ocean to decadal changes in wind forcing. J Clim 25(1):99-110. doi: 10.1175/2011JCLI4204.1

Mikaloff Fletcher SE, Gruber N, Jacobson AR, Gloor M, Doney SC, Dutkiewicz S, Gerber M, Follows MJ, Joos F, Lindsay K, Menemenlis D, Mouchet A, Müller SA, Sarmiento JL (2007) 
Inverse estimates of the oceanic sources and sinks of natural $\mathrm{CO}_{2}$ and the implied oceanic carbon transport. Global Biogeochem Cycles 21:GB1010. doi:10.1029/2006GB002751

Moreno PI, Lowell TV, Jackobson Jr GL, Denton GH (1999) Abrupt vegetation and climate changes during the Last Glacial Maximum and last termination in the Chilean Lake District: a case study from Canal de la Puntilla $\left(41^{\circ} \mathrm{S}\right)$. Geografiska Annaler Series A 81(2):285-311

Omta AW, Dutkiewicz S, Follows MJ (2011) Dependence of the ocean-atmosphere partitioning of carbon on temperature and alkalinity. Global Biogeochem Cycles 25(1):GB1003. doi: 10.1029/2010GB003839

Pahnke K, Zahn R (2005) Southern Hemisphere water mass conversion linked with North Atlantic climate varibility. Science 307:1741-1746. doi:10.1126/science. 1102163

Pahnke K, Goldstein SL, Hemming SR (2008) Abrupt changes in Antarctic intermediate water circulation over the past 25,000 years. Nat Geosci 1:870-874

Parekh P, Follows MJ, Boyle EA (2005) Decoupling of iron and phosphate in the global ocean. Global Biogeochem Cycles 19:GB2020. doi:10.1029/2004GB002280

Parekh P, Follows MJ, Dutkiewicz S, Ito T (2006) Physical and biological regulation of the soft tissue carbon pump. Paleoceanography 21:PA3001. doi:10.1026/2005PA001258

Peacock S, Lane E, Restrepo JM (2006) A possible sequence of events for the generalized glacial-interglacial cycle. Global Biogeochem Cycles 20:GB2010. doi:10.1029/2005GB002448

Ridgwell A, Zeebe RE (2005) The role of the global carbonate cycle in the regulation and evolution of the earth system. Earth Planet Sci Lett 234(3-4):299-315

Rojas M, Moreno P, Kageyama M, Crucifix M, Hewitt C, Abe-Ouchi A, Ohgaito R, Brady E, Hope P (2009) The southern westerlies during the last glacial maximum in pmip2 simulations. Clim Dynam 32(4):525-548. doi:10.1007/s00382-008-0421-7

Russell JL, Dixon KW, Gnanadesikan A, Stouffer RJ, Toggweiler JR (2006) The Southern Hemisphere westerlies in a warming world: propping open the door to the deep ocean. J Clim 19:6382-6390

Russell JL, Stouffer RJ, Dixon KW (2006) Intercomparison of the southern ocean circulations in ipcc coupled model control simulations. J Clim 19(18):4560-4575. doi:10.1175/JCLI3869.1

Saenko OA, Fyfe JC, England MH (2005) On the response of the oceanic wind-driven circulation to atmospheric $\mathrm{CO}_{2}$ increase. Clim Dynam 25:415-426
Sarmiento JL, Toggweiler JR (1984) A new model for the role of the oceans in determining atmospheric $\mathrm{pCO}_{2}$. Nature 308:621-624

Shakespeare CJ, Hogg AM (2012) An analytical model of the response of the meridional overturning circulation to changes in wind and buoyancy forcing. J Phys Oceanogr 42(8):1270-1287. doi:10.1175/JPO-D-11-0198.1

Shulmeister J, Goodwin I, Renwick J, Harle K, Armand L, McGlone MS, Cook E, Dodson J, Hesse PP, Mayewski P, Curran M (2004) The Southern Hemisphere westerlies in the Australasian sector over the last glacial cycle: a synthesis. Quat Int 118-119:23-53. doi:10.1016/S1040-6182(03)00129-0

Siegenthaler U, Wenk T (1984) Rapid atmospheric $\mathrm{CO}_{2}$ variations and ocean circulation. Nature 308:624-626

Sigman DM, Boyle EA (2001) Antarctic stratification and glacial $\mathrm{pCO}_{2}$. Nature 412:606

Takahashi T, Sutherland SC, Sweeney C, Poisson A, Metzl N, Tilbrook B, Bates N, Wanninkhof R, Feely RA, Sabine C, Olafsson J, Nojiri Y (2002) Global sea-air $\mathrm{CO}_{2}$ flux based on climatological surface ocean $\mathrm{pCO}_{2}$ and seasonal biological and temperature effects. Deep-Sea Res II 49:1601-1622

Toggweiler JR, Russell JL, Carson SR (2006) Midlatitude westerlies, atmospheric $\mathrm{CO}_{2}$ and climate change during the ice ages. Paleoceanography 21. doi:10.1029/2005PA001154

Trenberth K, Olson J, Large W (1989) A global wind stress climatology based on ECMWF analyses. Technical report., NCAR/TN-338+STR, National Centre for Atmospheric Research, Boulder, Colorado, USA

Tschumi T, Joos F, Parekh P (2008) How important are the Southern Hemisphere wind changes for low glacial carbon dioxide? Paleoceanography 34:PA4208. doi:10.1029/2008PA001592

Viebahn J, Eden C (2010) Towards the impact of eddies on the response of the southern ocean to climate change. Ocean Model 34:150-165. doi:10.1016/j.ocemod.2010.05.005

Wanninkhof R (1992) Relationship between wind speed and gas exchange over the ocean. J Geophys Res 97:7373-7382

Williams RG, Follows MJ (2011) Ocean dynamics and the carbon cycle: principals and mechanisms. Cambridge University Press, Cambridge

Zickfeld K, Fyfe JC, Saenko OA, Eby M, Weaver AJ (2007) Response of the global carbon cycle to human-induced changes in Southern Hemisphere winds. Geophys Res Lett 34:L12712. doi:10.1029/2006GL028797 